\title{
The Political Economy of Finance
}

\author{
Stephen Haber and Enrico Perotti
}

February 7, 2008

This survey reviews the recent literature on the political economy of financial development. Our goal is to highlight the impact of political institutions on financial structure, broadly defined to include not just the size of capital markets and banking systems but also the accessibility of finance, which is to say its distribution across firms and individuals. ${ }^{1}$

A broad literature has studied the effect of financial development on economic growth (Levine, 200?). More external funding of private activity precedes economic growth, a result that appears robust to endogeneity (see King and Levine, 1993; Beck, Levine and Loayza 2000). In particular, its effect is not just to accommodate the accumulation of productive capital but to improve the allocation of resources (Wurgler, 2000). . Financial development appears to fuel growth in financially dependent and emerging sectors (Rajan and Zingales, 1998; Fisman and Love, 2005). Yet this evidence does not establish finance as an independent source of growth. To appreciate the role of finance in growth, we need to understand the ultimate determinants of financial structure. Finance is the study of contracts granting income and control rights over assets. Contracts, by separating ownership and control, allow specialization and diversification. But, the willingness of agents to invest in contracts requires reliable protection of investor rights (LaPorta et al., 1997, 1998; Modigliani and Perotti, 2000). In the modern view of development, this requires supporting "institutions", defined as "the rules of the game" governing economic exchange and control over resources and support long term accumulation (North 1990). Thus real investment, financial development, technology and even education (as accumulated human capital) are all endogenous mechanisms (or “manifestations”) of growth, rather than its primary determinants.

\footnotetext{
${ }^{1}$ A more general definition includes access to retail financial services (Beck et al, 2006; Claessens and Perotti, 2007) and the allocation of risk bearing, discussed later in the section on financial crises.
} 
So what are the fundamental institutions that drive financial development? The literature has identified three main candidates: legal, cultural, and political institutions. Common law countries have more developed capital markets in contemporaneous crosscountry studies (LaPorta et al 1997, 1998). ${ }^{2}$ Persistent cultural values such as religion or trust have been shown to contribute to financial development (Stulz and Williamson, 2003; Guiso, Sapienza and Zingales, 2004). The seminal work of North and Weingast (1989), has identified the establishment of a limited government (i.e. political power constrained from arbitrary action) as a precondition for financial accumulation. ${ }^{3}$

This survey will not compare the relative contributions of each of these factors, an unsettled question about which there are extensive reviews (e.g. Beck, Demirgüç-Kunt and Levine, 2003, Acemoglu and Johnson, 2005). We take the view that the contributions of legal and cultural factors are complementary to political institutions and hard to disentangle. For instance, legal enforcement requires support by the executive branch, while in turn any judicial review of legislation constrains the choices available to the executive. Similarly, greater state influence, or social norms facilitating resistance by citizens to arbitrary government actions, may reflect cultural preferences or beliefs (for a related reinterpretation of the role of legal origin, see LaPorta et al, 2007). Tabellini (2007) identifies cultural norms as a critical transmission channel for persistence in political institutions.

The time invariant nature of legal origin and persistent culture characteristics implies that they are not good candidates to explain rapid changes in financial structure. ${ }^{4}$ In contrast, changes in formal political institutions are natural candidates to explain the emergence (and decline) of modern banking in free Italian cities during the Renaissance, the earlier development of financial activities in the Netherlands and Britain relative to their autocratic counterparts (de Vries and van der Woude, 1997), or even the involution

\footnotetext{
${ }^{2}$ The result of an independent effect of legal origin is robust to introducing political variables, such as formal democratic status. LaPorta et al (2007) argue that judicial independence and less formalized procedures create a more adaptable contracting environment which favors financial development. ${ }^{3}$ This relationship is also found both in cross-section (Barth, Caprio, and Levine 2006) and within countries over time (Haber, North, and Weingast 2007).

${ }^{4}$ Legal systems do evolve in response to economic pressures when politically supported. Horwitz (1976) documents how common law in the US evolved a novel view of property rights which supported a more intensive use of resources by emerging commercial and industrial interests.
} 
of private corporations in Ancient Rome in the transition from the republican system to the empire (Malmendier, 2005).

To avoid a vacuous claim that financial systems change because political institutions change, a clear theoretical framing with precise testable implications and natural experiments are necessary. This survey summarizes the recent literature on the political economy of finance, which explicitly models how political systems with different degree of political participation shape financial structure, interprets the emerging evidence, and highlight studies relating political shocks to structural changes in financial systems.

An important early contribution has established that limited government is a preconditions for financial accumulation (North and Weingast, 1989). More recent work indicates that the degree of access to political rights by citizens strongly affects their access to finance. Rajan and Zingales (2003, 2003a) forcefully argue that controlling access to finance is an ideal barrier to competition, as it is stealthy and not easily verifiable. In countries where political rights are concentrated, established interests lobby public officials so as to control financial access, creating and capturing rents. ${ }^{5}$ Recent studies have identified evidence on the capture of financial regulation in emerging financial systems and developed countries with diffuse corruption. These economies tend to have poor investor protection, narrow access to external finance controlled by state- or family controlled banks, and small stock markets dominated by a few diversified, often family-run business groups. Countries with poor political institutions exhibit greater financial instability (Acemoglu et al 2003), even though they tend to have restrictive regulation of competition in the financial sector (Barth, Caprio, and Levine, 2006). This suggests that poor political accountability allows established interests to abuse investor money and tolerates risk shifting. Under such condition of regulatory capture, financial liberalization tends to lead to financial crises with unfair distribution of gains and losses. Such crises are often blamed on free financial markets as inherently unstable, supporting political pressure for illiberal solutions which are in turn easily captured. Given the importance of finance for growth, this may create serious underdevelopment traps.

\footnotetext{
${ }^{5}$ This view is in the tradition of Stigler (1971), who argues that large businesses routinely capture their regulators.
} 
An important dynamic implication of the political economy approach is that the breadth of financial intermediation should increase as a broader section of the population achieves political representation, leading to broader access to finance and more competition. These implications have received much recent support (Benmelech and Moskowitz 2007; Perotti and Volpin, 2007; Rajan and Rechamandan, 2007).

However, the relationship is not necessarily monotonic. Beyond some threshold of political participation, broader political access does not necessarily result in more financial development, broader access and increasing competition. The evidence of large differences in financial structure across developed countries, incorporated in conventional views of Anglo Saxon versus Continental European financial systems, is only in part explained by legal differences (LaPorta et al, 1997, 1998). This has encouraged explicit models of democratic choice over financial structure which offer precise testable implications.

The review describes closely recent work which interprets the Great Reversals phenomenon identified by Rajan and Zingales (2003) as the outcome of a major political shock. A recent explanations suggest that a democratic majority in countries hit by a major redistribution of wealth may shift to favor low minority investor protection and less corporate restructuring and competition, to protect established labor rents. The pivotal middle class or a coalition of major interest groups may favor a "social market" approach where inside capital and inside labor interests shape financial structure over those of dispersed investor and consumers (Pagano and Volpin, 2005, Perotti von Thadden 2006).

It is important to state what this survey does not set out to do. It is beyond our scope to explain political evolution. Various original conditions, such as legal origin, climate, and competition among states, have been proposed (LaPorta et al, 1997, 1998; Engermann and Sokoloff 1997, 2002; Acemoglu, Johnson, and Robinson 2001, 2002). ${ }^{6}$ This review does not review the public choice literature, the effect of politics on macroeconomic policy, or normative models of financial structure. It does not seek to disentangle political ideology from economic preferences. Ideologies at the extreme of

\footnotetext{
${ }^{6}$ Recent evidence suggests that initial endowments has an independent contribution to explain contemporaneous financial development as much as legal origins do (Beck, Demigurck-Kunt and Levine 2003; Levine 2005).
} 
the political spectrum share a preference for limits to free trade and competition. ${ }^{7}$ There is little evidence that right-left ideology shapes outcomes once one controls for political or legal structure. Inside labor and inside capital may form corporatist alliances against dispersed investors (Pagano Volpin, 2005; Perotti von Thadden, 2006). Right wing governments may distort financial market outcomes to affect their chance of re-election (Aghion and Bolton 1990; Biais and Perotti 2002).

In Section One we discuss the emergence of limited government-the creation of safe property rights for at least a subset of the population-as a precondition for financial development. In Section Two we present two case studies which briefly review the US and Mexico experience with political and financial development. This leads us to introduce a broader discussion on political regimes with limited political participation, and explore how financial regulation, and thus access to finance, varies with the degree of political accountability. In Section 3 we look in particular at evidence on direct state interference in allocating finance, at indirect political influence when regulation is captured by special interests, and at their effects on financial stability. In Section Four we focus on variation in financial structure among representative democracies.

\footnotetext{
${ }^{7}$ Ideological explanations often fail to explain many historical turning points. Many radical liberalizations of financial systems in Europe and Latin America have been implemented under left government (as in Spain, France, Italy, Argentina). At the same time, the corporatist policies which constrained product and financial markets after WW2 in most Continental European countries were implemented by center right governments.
} 


\section{Section 1 Political Regimes and Financial Structure}

A common point of departure is that financial accumulation and intermediation concerns fungible, transferable wealth which is uniquely vulnerable to expropriation. Thus, a fundamental condition for the development of financial contracting is that opportunism be constrained by some institutional force. While a variety of market- or society-based contract enforcement mechanisms may exist, contracting among strangers in anonymous markets, the essence of modern financial intermediation, cannot thrive without some unbiased enforcement of contractual rights by those holding power.

The government's position as arbitrator of financial contracts, regulator of the financial system, and potential borrower creates, however, a potent source of opportunism. The state can fail to repay loans, seize assets, banks or firms, or take regulatory steps that amount to de facto expropriation. It may also fail to support judicial enforcement of contracts to favor connected interests. Because of this conflict of interest, political institutions are needed to limit the discretion of government actors, as precondition for legal institutions. ${ }^{8}$ Even if the protection of investor rights were neither the sole nor the most critical outcome of better political institutions, it may well represent an ideal litmus test, given the vulnerable nature of financial contracting.

\section{From Anarchy to Autarchy}

Anarchy arises when no central authority achieves a monopoly on violence, so that factions fight for control over resources, a situation described by Olson $(1993,2000)$ as "roving banditry". By definition, under anarchy there is no entity that can guarantee property rights, and competition among warring factions implies that any delay in seizing assets weakens their ability to fight. Anarchy thus undermines any property accumulation and transacting, and all the more so the financial system. Indeed, in periods when there were no stable state institutions, such as during the early Middle Ages, there is no record of financial transactions. Private property rights over land, well defined under the Roman

\footnotetext{
${ }^{8}$ This conclusion presumes a broader definition beyond formal political institutions, and may embrace cultural attitudes towards power which allow citizens to coordinate their actions to limit abuse by the executive.
} 
Empire, took centuries to be re-established after the barbaric conquests. The earliest financial contracts to allow for trade finance and safe payments at a distance were enforced via clan linkages (see Greif, 1993 on the Maghrebi traders), or religious associations such as the Templars. No arm length finance could exist among strangers.

Maurer (2002) explores a historical case of financial retreat under anarchy caused by the Mexican Revolution of 1910-20. Every competing faction preyed upon the banking system to extract resources to fight for territorial control. Within a few years of Mexico's civil conflict, the banking system had become a shell, stripped of all its assets. The incentives to prey upon banks were considerably stronger than in manufacturing, mining, or agriculture (Haber, Razo and Maurer 2003), since its assets are highly redeployable. Real assets tend to be illiquid, as their value depends on the application of specific skills, which helps to protect their owners expropriation. ${ }^{9}$

Anarchic societies cannot sustain economic activity, so they are inherently unstable. At some point power becomes concentrated by foreign conquest or the emergence of an authoritarian leader who defeats or co-opts opposing factions. The influential work of Olson (1993, 2000) and McGuire and Olson (1996) modeled dictators as an improvement over anarchy, achieved by "stationary bandits" who established military superiority over all competitors.

A dictator should in theory protect property rights, invest in public goods, and tax the economy at a long-run revenue-maximizing rate. Yet once capital has been accumulated, he faces no sanction for breaking his promises. The lack of commitment associated with absolute control is a main cause for the failure of the political Coase theorem in Acemoglu (2003).

In the Middle Ages, as power become centralized and more stable, some contractbased finance emerged gradually as merchant courts were formed in a few European market towns. Some "free cities" even paid off the local lord in order to enjoy political autonomy and protection from expropriation. Funds accumulated by these town bankers were occasionally lent to the king. Yet for several centuries, periods of peaceful

\footnotetext{
${ }^{9}$ Rajan and Zingales (2003a) argue that the high productivity of English yeomen who had bought expropriated church land in the XVI century protected them from expropriation. Their emergence created a broader constituency supporting property rights and limited government.
} 
accumulation were followed by sudden royal defaults or seizures. ${ }^{10}$ The kings of France, Britain and Spain had a tradition of bankrupting their Genoese, Florentine and Jewish lenders, as well as debasing their coinage. Kings often limited competition to create rents, and often created and sold monopoly rights. Yet these entitlements were often seized or reassigned, especially when kings came under military pressure.

Inability to commit causes a loss of state capacity. The lack of safe payment and credit mechanisms reduces economic activity and military capacity. Stable autocratic regimes may thus seek to create some financial accumulation and intermediation via state control, such as royal mints or royal banks, largely targeted at financing state expenditures. An early example of state banks comes from the creation by Egyptian pharaohs and Mesopotamian rulers of a system of state controlled granaries, which lent to farmers at very high rates while arranging for a rudimentary payment systems. State control over finance and limits to private banks was also sought by autocrats to avoid creating power centers which may challenge their authority, as in Tsarist Russia (Anan’ich 1999). Contemporary examples include Iraq under Saddam Hussein or Haiti under François and Jean Claude Duvalier, countries with no financial markets, except for a small state banking sector. ${ }^{11}$

Autocracy may be easy to describe but its distinctive features are often hard to identify empirically. In political science, the consensus is that no single institution, such as a constitution, electoral suffrage, or the existence of political parties, marks the transition to limited government and democracy. More often than not, authoritarians rule through constitutions, staged elections, ${ }^{12}$ and use political parties that align the incentives of the officer corps with the dictator. ${ }^{13}$ There are even de facto autocratic political

\footnotetext{
${ }^{10}$ Cortes Conde (1999) studies a classic case of financial regression under an unconstrained dictator. From 1829 to 1852 Argentina fell under the control of the strongman Juan Manuel de Rosas. The private chartered banks that existed prior to his rise to power were pillaged, and reappeared only once the dictatorship was overcome.

${ }^{11}$ In the modern definition of ownership as the set of decision rights residual to contractual and legal obligations (Hart, 1995), the set of property rights under autocracy is empty: all decisions over assets ultimately reside with the dictator.

12 In some cases, such as the Brazilian military junta of 1964-85, elections were an integral part of creating a stable system: citizens voted for legislators from either of two political parties, who operated as an electoral college to decide which of Brazil's generals would serve as president.

${ }^{13}$ A prominent example is Alfredo Stroessner, the military strongman who ruled Paraguay from 1954 to 1989, who took over a debilitated political party, the Colorados, and turned it into an immense patronage machine designed to align the incentives of the officer corps with his regime.
} 
systems that are purely party based, such as Mexico under the PRI (1929 to 2000), or Malaysia under the UMHO (1957 to the present)).

Totally unconstrained dictators are actually quite rare. Even in the absence of formal institutions, autocrats face competition for power from political competitors who may succeed in removing them from power by force. ${ }^{14}$ The vast majority of dictators are removed not by uprisings or democratic transitions but by internal coups (Tullock 1987), which tend to re-establish a similar autocratic government. Potential competition for power causes dictators to share power with individuals in control organizations - the military, the police, and the bureaucracy. Individuals in these control organizations are often, therefore, potential veto players who limit dictators' arbitrary authority, and, as a consequence, must be granted some share in the wealth captured by the political system. Thus autocratic governments grant entrenched privileges to a connected elite, which include statutory monopoly rights, barriers to entry that reduce competition (including limiting bank charters), preferential treatment in the courts, and exemptions from taxation. In short, in order to encourage investment, autocrats restrain competition to favor a small, hand picked elite, either to assign rents to essential political supporters, or to offer to privileged investors rates of return high enough to compensate them for residual expropriation risk. Examples of shared control over the financial system which mingles the financial interests of the economic and the political elite have been observed in recent years in Liberia, Indonesia and Russia. This allows capital accumulation limited to a small oligarchy even under unlimited government.

A classic story of economic entrenchment via control over finance is Mexico during the regime of Porfirio Díaz (1876-1911). Maurer and Gomberg (2005) have shown how it was necessary for the Mexican government to create official monopolies so as to compensate bankers for expropriation risk. Bankers aligned their incentives with the politicians by giving them lucrative positions on bank boards of directors (Maurer 2002). Razo (forthcoming) has constructed an exhaustive network analysis of Mexico’s politicians (at both the state and federal levels) and investors in every partnership and corporation formed from 1884 to 1911 . He shows how the more a particular firm required

\footnotetext{
${ }^{14}$ The idea that pure autocratic rulers are inherently insecure was common among thinkers of antiquity, such as Thucydides, Plato, and Aristotle (Ober 1998), and is one of the central preoccupations of Machiavelli's The Prince (2005). See also ]Tullock 1987; Bueno de Mesquita et. al 2003; and Haber 2006.
} 
special concessions, the more likely it was to award seats on its board to powerful politicians. In particular, banks were the firms with the largest number of influential politicians on their boards. Haber (1991, 1997, 2003, 2005), Maurer (2002), Haber, Razo, and Maurer (2003), and Maurer and Haber (2007) describe how this politically connected banking industry created differential access to capital, and sustained high levels of concentration in downstream industries. As a result, the Mexican textile industry was much more concentrated, as well as less efficient, than in Brazil. Brazil had, thanks to its federalist structure, a more decentralized power distribution, which led to less concentrated capture of rents, more developed financial markets and more competitive industry.

Barth, Caprio, and Levine (2006) analyze a cross section of 65 countries in 2003, offering similar results on the relationship between political institutions, access to finance and entrenchment. They find that countries with more autocratic institutions tend to be less permissive of bank entry and tend to create more regulatory restrictions on banks. Tight regulatory restrictions on banks are associated with lower credit market development and less bank stability, as well as with more corruption in lending. The regulatory framework in these countries tend to discourage the private monitoring necessary for the dissemination of independent information, a necessary condition to maintain political control over the allocation of capital. More autocratic countries also use state banks to direct credit toward the interests of the politically powerful, and limit competition in banking. This is consistent with a goal to protect incumbent banks, while creating regulatory restrictions so that bankers need to lobby for special exemptions. In short, there appears to be a strong association between strict regulatory constraints limiting financial development and entrenched established interests. The frequency of diversified conglomerates suggests that competitors to established firms face limited access to resources. In contrast, in developed markets, investors frown upon unfocused conglomerates, which appear to under perform focused firms.

In conclusion, societies with weakly limited government are dominated by an alliance between a political elite and an entrenched economic elite that enjoys special privileges. By its nature, this system maintains high oligopolistic rents and financial barriers to entry, and fails to enable individuals outside the elite to access resources. 


\section{The Emergence of Limited Government}

The previous section illustrated how autocrats may create some incentives to invest for a small elite. Transferring some rents to individuals or organized groups whose support the government needs in order to remain in power creates some commitment power; were the state to seize the assets, it would cause a withdrawal of crucial support (Haber, Razo, and Maurer 2003). A more solid institutional basis for this commitment, however, requires the devolution of some power to those individuals able to challenge executive power. Acemoglu and Robinson (2006) show how a ruling elite will agree to an expansion of political rights to credibly limit executive power in the future. Vesting some power to a broader group constrains the executive ability of any rival who may seize power in the future, and be tempted to fully expropriate the old elite.

Limited government arises when the authority of public officials is constrained by institutions which grant political power to some fraction of the population. The political access hypothesis predicts that explicit rules will be established to protect the specific property rights held by this group (for instance, voting in parliamentary elections were initially reserved to landowners). This group will form an economic elite that defines its status by explicit rules and rights rather than by political appointment or personal privileges.

The first recorded example of such a government is Athens (Ober 1988), where governance by citizen assemblies was clearly distinct from the autocratic style of government elsewhere, and supported a thriving economy centered around open trade. In the modern world, the first examples are Italian city states such as Genoa or Venice and the sixteenth century Dutch Republic, in which a powerful merchant class effectively ruled the country. The resulting credibility toward creditors set off a revolution in private finance (de Vries and van der Woude 1997; Neal 1990).

Entrenching strong rights for an elite, however, create a self reinforcing process, as privileged interests will resist any loss of privileges (Acemoglu, Johnson and Robinson, 2005). Oligarchic economies may have very strong protection of traditional property rights (e.g. land ownerships and servitudes) but discourage any institutions (education, 
reliable contracting) that may grant access to resources to emerging groups. These economies will ultimately lag behind others, once technological shifts demand human capital accumulation and labor specialization (Aghion, Alesina and Trebbi, 2007). ${ }^{15}$

The classic study of the emergence of limited government, and its impact on financial development, is North and Weingast's (1989) analysis of England's Glorious Revolution of 1688 . After 1688, the Crown could no longer call or disband parliament, which gained the exclusive authority to raise new taxes and to audit Crown expenses. The Crown also lost prerogative powers over courts, and was made subject to the common law, while the judiciary was made independent. Parliament created the Bank of England, to which it delegated financing of state expenditures, thereby also tying the hands of future Parliaments. North and Weingast (1989) argue that these institutional innovations assured the government's creditors that state loans would be repaid. ${ }^{16}$ The result was a boom in public finance that allowed the British Government to borrow from private capital markets at rates that were unimaginable prior to 1688 , thereby financing England's rise to global military hegemony. North and Weingast also argue that the creation of a stable market for public debt sustained the parallel development of a market for private debt, a necessary input to England's subsequent industrial revolution.

More recent research indicates, however, that North and Weingast paint too rosy a picture of the effects of limited government on private financial development. The same political institutions that allowed debt holders in parliament to block the sovereign from defaulting also allowed them to create an oligopolistic structure of private finance. Limited liability was granted extremely sparingly, and only upon an act of Parliament. The Bank of England was established with a monopoly on the corporate form. Parliament granted first a temporary charter, which had to be renewed regularly until 1844, forcing each time a deal in which the government obtained financial support in exchange for specific privileges generating rents for the Bank of England's shareholders (Broz and Grossman 2004). All other banks of issue had to operate as partnerships, with at most six

\footnotetext{
${ }^{15}$ The elite may prefer weaker property rights if their interests are guaranteed via direct arrangements with public officials, while weak legal rights enables them to prey on the assets of other members of society (Sonin, 2003).

${ }^{16}$ Stasavage (2003) shows that Parliament constrained the British king from defaulting on its debt because debt holders were able to join coalitions with other legislators, trading their support on other issues in exchange for support on debt repayment.
} 
partners, and thus forego the advantages of limited liability and tradable shares. Cottrell and Newton (1999) argue that excessive privileges for the Bank of England were not positive for Britain's early financial development.

Summerhill (forthcoming) describes the related example of Imperial Brazil (18221889), where the Crown was limited by a Parliament and a Council of State which checked its ability to default on the public debt. Imperial Brazil constitutes a striking contrast to twentieth century Brazil, and to the rest of Latin America: it never defaulted on its public debt, and had a vibrant domestic debt market with low interest rates. But, the establishment of safe property rights for a few investors did not necessarily lead to broad and thriving financial access. Until the end of the monarchic regime, Brazilian private financial development was modest. Summerhill (forthcoming) argues that the political institutions that limited the ability of the sovereign to default on the public debt—a parliament in which debt holders were represented—also created a mechanism by which incumbent bankers could limit entry by new competitors, e.g. by limiting incorporation laws or the chartering of new private banks.

Consistent with the political economy view of financial development, Brazil's private sector finance developed only after the fall of the monarchy in 1888 . The creation of a federal republic undermined, for a time, the arrangements that had supported a small and concentrated banking system and financial markets. The central government no longer had a monopoly on the chartering of banks or the chartering of corporations, after the 1891 Constitution gave each of Brazil's 20 states considerable sovereignty. This put the federal republic's first finance minister, Rui Barbosa, under considerable pressure: if he did not grant additional charters to new banks and corporations in order to satisfy the demand for credit from Brazil's growing regional economic elites, they would get their own state governments to do so. As a result, Rui Barbosa, quickly pushed through a series of financial reforms: the federal government allocated bank charters to virtually all comers through a general incorporation law; banks could engage in whatever kind of financial transactions they wished, including the right to invest in corporate securities; the liability of shareholders was limited to the face value of their shares; and the rights of creditor and shareholders were enhanced. (Haber 1998, 2003; Musacchio 2007). Indeed, as Musacchio (2007) has shown, circa 1913, Brazil had among the strongest creditor 
rights in the World. In the short run, these reforms had dramatic effects on the growth of banks and publicly traded firms. Within three years, the number of banks in Brazil nearly tripled. A spate of IPOs caused the securities markets to expand six-fold. (Haber 2003).

In the medium term, however, political power was quickly concentrated again in a powerful federal executive. While the republic had extended political rights, still less than five percent of the population had the right to vote. At the same time, the two largest states (Sao Paulo and Minas Gerais) formed a coalition, taking advantage of the fact that the president was indirectly elected by congress, and traded the presidency between them. The end result was that congress soon became more of a consultative forum than a body that initiated legislation or checked the federal executive. This meant that when the central government found itself pressed for funding it was able to put legislation into place that on the one hand limited the activities of private commercial banks, and on the other, created a semi-official bank designed to finance the state (the fourth Banco do Brasil) in which the government both owned shares and named its president. (Triner 2001; Hanley 2005). The republican government did not, however, have strong incentives to reverse the reforms governing corporate securities. Thus, massive equity issues on the Rio de Janeiro and Sao Paulo markets generated a rapid spurt in industrial development Haber $(1997,1998,2003)$ contrasts Brazil's post-1889 thriving financial markets with Mexico, where tight control by a narrow elite suffocated equity markets. The final result was that Mexico had not just less industrial development, but also much less competition in industry, stunting its development. 


\section{Section 2: The broadening of political participation}

A significant increase in political participation in Europe took place during the nineteenth century. The French revolution produced a violent shock to the traditional ancien regime, abolishing aristocratic privileges, redistributing church land and streamlining access to justice with the Code Civil. After the Restoration, most countries responded to increasing political unrest at first by a traditional repressive approach. After a period of increasingly frequent riots and the Paris revolution of 1830, the traditional British elite saw the necessity to grant a progressive expansion of political rights to reflect the emergence of industrial and commercial interests along with its Industrial Revolution. The 1832 Reform Act was a first step in a process of expanding suffrage rights for males to broader social groups outside property owners, in the process creating a political basis for broader access to economic opportunities. The liberalization of entry in banking took place alongside the progressive expansion in suffrage, just as in France and other continental European states. The broadening of voting rights was even faster in the US, whose federal structure created competition across states to attract population (Keyssar 2000). Benmelech and Moskowitz (2005) show how this expansion of suffrage improved access to finance.

In the second half of the nineteenth century the political emancipation of the merchant and industrial class as well as a massive expansion in colonial trade created demand for financial expansion. Thanks to its earlier development of limited government, Britain had an advantage in financial contracting, but even its financial system needed to become more open and competitive to satisfy booming demand for capital. The new entrepreneurial class also created pressure for legal development. English and American courts moved away from traditional notions protecting established rights and servitudes, for instance in land use and strict liability, which constrained the more intense use of assets required by industrial activities. Horwitz (1976) illustrates the evolution of US legal practice away from agrarian principles and toward the more utilitarian interests of an entrepreneurial class. This period sees also the relaxation of constraints on financial institutions and the diffusion of the right to incorporate under limited liability. 
Under the push of new industrial and trade opportunities, the interests of the emerging classes became enshrined in more commercially oriented legislation and in relaxed regulation also in Continental Europe, as in France under Napoleon III. ${ }^{17}$ The early advantage in financial development Britain had enjoyed was eroded, as Continental European capital markets funded rapid capital accumulation. Codification removed many barriers to commerce and industry arising from traditional rights and servitudes, reduced the cost of contractual transacting. Commercial codes for many forms of contracting were progressively introduced also in common law countries by the end of the century, to facilitate trade among diverse individuals across greater distances and to enhance the liquidity of financial claims (Gennaioli and Perotti, 2007).

This process of broader political and economic access was gradual. In the political economy interpretation, financial development went along with broadening of political rights; in other words, access to political rights created access to finance. Clearly, the fact that these trends developed in parallel is no proof of causation per se. We therefore look in detail at two informative cases: the United States and Mexico.

\section{The US as a case study}

What explains changes in the distribution of political rights is a crucial question in political science, and is well beyond the scope of this survey. However, it is useful to describe the history of politics and financial development in the case of a single country. For this purpose we present here a very abbreviated historical reading of the US experience.

One advantage is that the US is a rare case of a nation founded on the notion of limited government, where basic private property rights were fairly secure from the start. As the US maintained its original legal orientation, while experiencing a progressive expansion in political representation, it is a uniquely useful case study to map the evolution of financial structure, and particular financial access, as a function of evolving

\footnotetext{
${ }^{17}$ For an analysis of progress in corporate law and finance in France, see Lamoreaux and Rosenthal, 2004; on Germany, see Franks, Mayer and Wagner, 2006.
} 
political accountability. While this temporal correlation per se does not establish causality, we discuss recent studies that hold considerable promise towards this goal.

The original political elite in the US was a coalition of established merchants and landowners who wrote the US constitution as a bulwark against central government, but with a traditional view on granting suffrage rights only to men of property. A leading explanation for the evolution in political representation in the US was the challenge to this model of limited political participation posed by the competition produced by new states steadily emerging on its frontiers (Keyssar 2000). These states were underpopulated and had a strong incentive to attract new settlers, and thus were keen to create generous economic opportunities and political rights. This competition caused steady pressure to increase suffrage in the original states, to open up economic opportunities and reduce entry barriers.

The origins of US financial development resemble the early British experience, transferred in a federal state setting. Sylla, Legler, and Wallis (1987) and Wallis, Sylla, and Legler (1994) show that America's states originally set out to create segmented monopolies, trading corporate charters for revenues. In virtually all of the original 13 states, the state government was granted bank shares as a "charter bonus." During 181030, bank dividends and bank tax payments often accounted for one-third of total state revenues. This process created incentives for incumbent banks to lobby or bribe state legislatures to deny charter applications by potential competitors, and historians describe clearly a process of captured regulation (Bodenhorn, 2003, 2006). ${ }^{18}$ The federal government pursued a similar strategy by chartering its own commercial bank, the Bank of the United States in 1791 (Sylla 2000). The federal government acquired a significant stake in this commercial bank at a preferential price, borrowing the funds from the bank itself.

This system of segmented monopolies was not consistent, however, with the country's political institutions, and in particular with a federal structure which attributed

\footnotetext{
${ }^{18}$ Gatell (1966), Bodenhorn (2003, 2006), and Moss and Brennan (2004) describe the behavior of individual legislators in the notorious case of New York state. From the 1810s to the late 1830s, bank chartering was controlled by the so-called Albany Regency - a political machine run by Martin Van Buren. Bank charters were only granted to friends of the Regency, in exchange for which legislators received bribes or were allowed to subscribe to initial public offerings of bank stock at par, even when the stock traded for a substantial premium.
} 
significant power to the states. Bank regulation was a state responsibility, and state legislators were accountable to their local commercial elites. Given the pull exercised by an expanding frontier, state legislatures were under considerable pressure to attract business enterprises and scarce capital and labor. This competition drove local elites to expand access to economic opportunities to match the conditions on offer in the new states. The most credible step was to broaden voting rights beyond property owners. Even if this process did not occur in lockstep, and there was considerable variation from state to state, the original 13 states were forced to respond by reducing their voting restrictions. By the mid-1800s, property qualifications had been dropped or dramatically reduced in virtually all of the original states (Keyssar 2000; Engerman and Sokoloff, 2002).

This expanded suffrage undermined the political coalitions that had supported restrictions on the number of bank charters, restrictive incorporation laws or stringent financial barriers (often camouflaged as usury laws). States also competed by building infrastructure (such as canals, ports or railways) funded by levying "bonuses" on new bank charters (Grinath, Wallis, and Sylla, 1997; Sylla 2000; Wallis and Weingast, 2004). The public funding raised by any new charter depended on the number of charters granted. At the same time, once a charter was granted, state legislatures had an incentive to renege on arrangements with incumbent banks. This political pressure affected even Southern states, which had a well established agrarian elite and were keen to protect their own banks (Bodenhorn, 2003: 86, 148, 152, 228-34). The result was the rapid growth of joint-stock banks. As competition grew, banks extended credit to an increasingly broad range of borrowers (Wang, 2006). Indeed, as Wright (1999) has shown, banks in America's Mid-Atlantic States lent overwhelmingly to a wide customer base of merchants, artisans, and farmers. ${ }^{19}$

A key feature of federalism was that the Federal Senate and House of Representatives were elected at the state level. As a consequence, the interests of new states were over-represented. Local economic elites could therefore influence federal banking policies and, at times, made alliances with populist groups that were entirely opposed to banks. Hammond (1947), Temin (1968), Engerman (1970), and Rockoff

\footnotetext{
${ }^{19}$ The practice of banks lending primarily to their own board members, detailed by Lamoreaux (1994), appears to have been a characteristic of the closer elite in New England (see also Bodenhorn 2003).
} 
(2000) explore how state bankers formed alliances with the Jeffersonians, who were ideologically opposed to chartered corporations and "aristocratic" bankers. As a result, when the Bank of the United States charter expired in 1811, Congress did not renew it. The winners, of this alliance, of course, were bankers with state charters, who now faced less competition. The Second Bank of the United States (chartered in 1816) met the same fate.

In some states, New York being the archetypal example, the extension of the suffrage allowed citizens to bring pressure to bear on legislatures, voting in legislators who were willing to challenge established privileges on bank charters or incorporation laws which limited entry. Once New York chose to broaden its electoral laws in 1826, Whig candidates soon obtained a majority and promptly reformed the state's banking laws, creating an institution known as "free banking," in which the state legislature no longer gave charters at all. Rather, banks were allowed to operate so long as they deposited bonds backing their note issues with the state comptroller. Bodenhorn (2003, 2006), Wallis, Sylla, and Legler (1994), and Moss and Brennan (2004) discuss how more permissive rules for bank chartering eventually forced other states to pass "free bank" legislation that made obtaining a bank charter a simple, administrative procedure. Some variant of the New York law was ultimately adopted in 21 states. The evidence suggests that free banking laws (e.g., Rockoff 1974, 1985, 2000; Ng 1985; Bodenhorn 1990; Economopoulos and O’Neil 1995) increased entry and contributed to rapid credit growth.

The causal relationship between the extent of electoral suffrage and a variety of financial regulations that restrict entry is studied by Benmelech and Moskowitz (2005), who exploit variation across time and across US states in the laws regarding suffrage, free banking, general incorporation, and interest rate ceilings (usury). They find that usury laws were used by industrial incumbents to control entry and lower their own costs of capital. Suffrage laws and financial regulatory policies appear strongly correlated: more concentrated voting laws are associated both with tighter usury laws (which restricts the supply of credit, in particular to newer, riskier firms) and the lack of general incorporation laws — even after controlling for state and year fixed effects. Finally, they find that the combination of policies most preferred by industrial incumbents- 
restrictions on voting and general incorporation, but free entry into banking-is strongly associated with the strictest usury laws.

A system of free entry was compatible with the fiscal needs of state governments because under free banking all bank notes had to be 100 percent backed by high-grade securities deposited with the state comptroller of the currency. Free banks were forced, in essence, to grant a loan to the state government in exchange for the right to operate.

Free banking did not eliminate all supply constraints on the number of banks. The free banking laws of the vast majority of states precluded the chartering of branch banks. Virtually all banks in the nineteenth century United States, except those in some southern states, were unit (single branch) banks. This unusual organization of the banking system was the outcome of an unlikely political coalition: populists who feared bank monopolies at the state level allied to bankers who wanted to create local monopolies.

From the point of view of the federal government, allowing the states to charter banks had a major drawback: it did not provide the federal government with a source of finance. This problem came to the fore during the Civil War, when the financial needs of the federal government skyrocketed. The federal government therefore passed laws in 1863, 1864, and 1865 that were designed to eliminate the state chartered banks and replace them with a system of national banks that would finance the government's war effort. ${ }^{20}$ Consistent with the goal of maximizing credit to the federal government, the National Banking Act made the granting of a charter an administrative procedure: as long as minimum capital and reserve requirements were met, the charter was granted. As Sylla (1975) pointed out, it was free banking on a national scale.

In the short run, the number of state chartered banks declined. In the long run, however, federalism undermined the barriers to entry in banking created by the National Banking System: states simply ratcheted downwards the requirements for a state license to open a bank. The result was that state chartered banks actually outgrew federally chartered banks during the period 1865-1914.

\footnotetext{
${ }^{20}$ Federally chartered banks had to invest one-third of their capital in federal government bonds, which were then held as reserves by the comptroller of the currency against note issues.
} 
The end result of this competition between states and the federal government was a banking system unlike that of any other country. In the first place, in 1914 there were 27,349 banks in the United States. In the second place, almost none of these banks had branches. The odd coalition between populists opposed to corporations and local bankers, who feared competition from large, multi-branch banks, meant that most states had laws that prevented branch banking, even by nationally chartered banks. Even those states that did not explicitly forbid branch banking had no provision in their laws for branches. Hence, as Calomiris and White (1994) have shown 95 percent of banks were unit banks, and the banks that did have branches tended to be small: the average number of branches operated by these banks was less than five.

The question of whether this highly unusual organization of the banking system was efficient is an empirical issue. ${ }^{21}$ The recent evidence is that technology allowing more distance between lender and borrower progressively made America's system of small unit banks increasingly obsolete. In 1994, a federal statute reorganized the sector, and forced reluctant states to explicitly opt out, thus creating an opportunity for public scrutiny over a decision strongly opposed by local lobbies. Kroszner and Strahan (1999) exploit variation across states in terms of state deregulation and in terms of how state delegations in the House and Senate voted on the 1994 federal act. They find that states with large numbers of small banks, who had the most to lose by deregulation, fought to maintain branching restrictions, while those with a small number of large banks were faster to deregulate and were more likely to vote in favor of national legislation that permitted branching. They also find that states with large numbers of small, bankdependent firms (who gain from deregulation, because it lowers their cost of credit) tended to deregulate earliest and tended to vote in favor of national deregulation. Black and Strahan (2002) and Cetorelli and Strahan (2006) find that more vigorous local banking competition across US states is associated with more funding for new firms, more firm entry, and a smaller average firm size. This suggests that even in the contemporaneous US economy, politically sanctioned limited competition in the financial sector may limit entry.

\footnotetext{
${ }^{21}$ A benevolent view of unit banking suggests that embedding banks into communities meant that bankers helped overcome information asymmetries by tapping into local networks (Lamoreaux, 1994).
} 


\section{Mexico as a case study}

Mexico was ruled by two long-lived regimes from the 1870s until 2000. In 2000 Mexico achieved the substantial transition to a democratic system, finally allowing a peaceful transition of executive power. This history allows us to study how the broadening of political rights has put pressure on the government to change the institutions that underpin the financial system.

As discussed earlier, from 1876 to 1911 Mexico was governed by a dictatorship that gave rise to an entrenched economic elite. That dictatorship was overthrown during the Mexican Revolution, which set off ten years of coups and civil wars. In the 1920s, political stability was again restored by the creation of an "official party." From 1929 to 1997 that party, the PRI, won every presidential election, dominated both houses of the legislature, controlled all the state houses, named the judiciary, controlled the press, and ran the educational system. So complete was the hegemony of the PRI that it was difficult to know, exactly, where the party ended and the government began.

The lack of checks on the authority and discretion of PRI-led administrations meant that incentives to invest were weak. This in turn, created a problem for the PRI: it needed to generate jobs and revenues for its core constituency of organized industrial and public workers that assured its electoral dominance. The PRI solved this problem the way many authoritarian governments do: it awarded a select portion of the country's business class with sets of special privileges designed to raise rates of return high enough to compensate them for expropriation risk These privileges included low levels of taxation, trade protection, and barriers to entry (Haber, Klein, Maurer, and Middlebrook, forthcoming).

What was true about the economy in general was particularly true about the banking system. As Maurer (2002) has shown, after the Mexican Revolution the new government actually invited the country's bankers to write the banking laws. Not surprisingly, the law they wrote limited competition by keeping foreign banks out of retail banking and by giving the National Banking Commission, on which the bankers were strongly represented, the right to limit the number of charters granted to new banks. The law also created a government-owned commercial bank, the Banco de México, 
which lent most of its funds to private bankers and powerful politicians. The Banco de México was not a central bank, rather a mechanism to protect private bankers' incentives to deploy their wealth in a country in which there was a very real threat of expropriation.

As soon as the PRI began to consolidate power, however, it began to whittle away at the policy-making authority that had been delegated to private bankers in the 1920s. In 1932, the government converted the Banco de México into a central bank. Four years later it began to require that commercial banks maintain cash reserves in the Banco de México, and it transferred many bank supervisory functions from the banker-influenced National Banking Commission to the Banco de México. This set up the conditions through which the government could engage in a creeping expropriation of the banking system through financial repression. As del Angel $(2002,2005)$ has shown, the private commercial banking system therefore remained of modest size (from the 1940s to the late 1970s its loans never exceeded seven percent of GDP) and the commercial banks operated as the treasury arms of non-financial conglomerates, rather than as the financial intermediaries of economic theory. By the 1970s the government was, in fact, using its supervisory authority to raise reserve rates in order to finance budget deficits—so much so that by the early 1980s the average deposit-reserve rate was 58 percent. In 1982, the government explicitly expropriated the banks, and for the next decade, Mexico's banks were used to finance budget deficits (Haber, Klein, Maurer, and Middlebrook, forthcoming).

In the early 1990s, the government decided to sell Mexico's banks to private investors as part of a broad program of privatization of state owned firms. Of course, any acquirer faced the risk of expropriation, and thus a new set of institutions designed to compensate investors by raising bank rates of return had to be created. These included poor accounting rules, an oligopolized market structure coupled to restrictions on new entry, unlimited deposit insurance, and provisions that allowed the bankers to fund the purchase of the banks with loans - some of which from the same banks they were buying (Haber 2005). The result of these institutions was that bankers and depositors had little capital at risk, and the government had created regulatory and accounting standards that amounted to extreme regulatory forbearance. A vertiginous run up in lending ensued, with many of the loans going to bank insiders. In 1995, just four years after the bank 
privatization took place, the government had to bail out the banks - at a cost to taxpayers that was four times the value that had been received for the banks at auction. Related loans defaulted much more frequently than ordinary loans, for amounts considerably larger, and had lower recovery rates (La Porta, López-de-Silanes, and Zamarripa 2003).

The political backlash caused by this bailout created broad pressure for a less captured financial system. The results included a reform of Mexico’s accounting rules and deposit insurance system, and a politically sensitive move to allow foreign banks to purchase Mexico's failed banks. Those foreign banks quickly discovered, however, that Mexico’s long history of authoritarianism meant the country was almost entirely lacking in institutions that could allow for the low cost enforcement of contracts: bankruptcy laws were archaic, the courts were inefficient, the police were corrupt, credit reporting was in its infancy, and property registers woefully inadequate, as credit had clearly never relied on such arm length instruments. After 1997, Mexico’s banks extended very little credit to firms and households, choosing at first to lend to the federal, state and municipal governments. Most bank profits came not from loans, but from their oligopolistic control over the payments system (Haber, forthcoming).

Changes in Mexico's political institutions have made these arrangements difficult to sustain. The PRI lost control of the lower house of congress in 1997, and lost control of the presidency in 2000, which also led to a fairer electoral process. Mexico is now a multi-party democracy, with intense candidate and party competition for office. The party that ousted the PRI from power, and that has controlled the presidency since 2000, has carried out a number of reforms designed to ease the scarcity of credit. It created a federal housing program designed to provide access to mortgage credit. It carried out a reform of Mexico’s bankruptcy laws, permitting banks and borrowers to write debt contracts in such a way as to put the collateral outside the borrower's bankruptcy estate. It has undertaken (modest) programs to systematize and rationalize the country’s property registers. And, at the end of 2006, it granted charters to six new retail banks, including one to be operated by Wal-Mart and another to be operated by a domestically-owned retail giant, so as to increase the degree of competition in the credit markets. These programs have, to some degree, borne fruit. The Mexican banking system is now stable 
and is prudently managed. Moreover, the dramatic decline in the availability of bank credit since 1995 was finally reversed in 2005. This improvement in credit access was most notable in consumer lending - $\mathrm{a}$ fact that the Mexico's recent governments have been quick to trumpet as evidence that its policies are working (Haber, forthcoming).

After these two case studies, we turn to a systematic review of evidence on political influence on financial structure and stability in countries with low to intermediate level of political accountability. 


\section{Section 3 The Political Capture of Finance}

\section{Section 3.1 ～Direct Political Intervention}

The state can influence directly the allocation of credit; either by state banking or by allowing concentrated ownership over banks, which are common in many developing countries. Caprio, Laeven and Levine (2007) show that in countries with poor investor protection, most banks have concentrated control by either a family or the state.

State banking has a long tradition. Already in the ancient world the state sought to ensure some direct control over the allocation of resources, not least to fund itself. State ownership may have been a necessity if no private institutions could have been trusted to pay taxes (Gordon and $\mathrm{Li}, 2006$ ). There is no evidence that state banks are a solution for diffusing access to finance. Development banks aimed at grassroots producers have mostly been captured by specific interests, becoming decapitalized and often ultimately insolvent. State banks often favor more established firms or state owned enterprises (Sapienza, 2004). Yet state banking persists to our days, even in the face of evidence of their inefficiency (Cull and Xu 2000; Clarke and Cull 2002; Clark, Cull, and Shirley 2005; LaPorta et al, 2002).

If political access is limited to a privileged elite, connected individuals will inevitably use it to obtain preferential access to capital, in particular from state owned banks. In emerging markets, even large firms have concentrated ownership, and usually belong to business groups. Such groups are defined as firms interlinked by formal (equity) and informal (family) ties, and dominate the public equity markets in these countries (Khanna and Yafeh, 2007). A traditional view saw them as efficient adaptations in an unreliable environment, creating internal capital and labor markets where none exist, and attracting funding based on their reputation. There is indeed evidence that group firms are less financially constrained, with funds presumably moving from firms rich in free cash flow to constrained firms. ${ }^{22}$ In developing countries, these groups often trade at a premium relative to stand alone firms, while diversified conglomerates in the West

\footnotetext{
${ }^{22}$ It is not always clear how much of the funds leaving cash rich firms is indeed reinvested rather than skimmed. In the case of Russia, the correlation between investment and cash flow is actually negative for group relative to independent firms (Gelfer and Perotti, 2001).
} 
trade at a discount (Fauver, Larry, Joel Houston and Andy Naranjo, 2003). ${ }^{23}$ Recent evidence on the determinants of better access to finance is much more critical. Countries where the list of major companies is more stable appear to have less developed equity markets and lower economic growth (Fogel, Morck and Yeung, 2006). Even though direct evidence that these groups enjoy privileged access and capture regulation is missing (Khanna and Yafeh, 2007), political access is always cited as one of their comparative advantages. A legitimate conjecture is that preferential access to finance for the groups is not unrelated to political pressure for limited access by other firms (Morck, Yeung and Wolfenzon, 2006).

Time series evidence suggests that the comparative advantage of groups declines with greater political accountability and more trade openness. In Chile, the relative valuation of group firms declined in the period 1980-1990, as major political reforms progressively led to a return to democracy (Khanna and Palepu, 2000). Identical results have been found for Korean chaebol business groups, which enjoyed their highest relative valuation and the easiest access to the state banking system during the dictatorship years, while both declined as the country restored democracy (Lee, Peng and Lee, 2001). The 1997 Asian crisis made quite visible the concentration of lending, and several chaebols came into serious financial difficulty, reinforcing the crisis in the domestic market (Campbell and Keys, 2002). After the crisis, the Korean government was forced by public opinion to adopt considerably stronger regulatory and governance standards, which supported a much faster recovery. A similar excessive concentration of lending risk to business groups became apparent in other Asian countries, such as Malaysia, Indonesia and the Philippines, just as it happened in previous crises in Chile and Mexico. In countries with less accountable political institutions, no comparable reform were implemented, nor did their financial systems recovered as well as in South Korea.

Recent studies provide direct evidence that firms with political connections enjoy more favorable financial access with state banks. They receive larger loans, and while they pay on average similar interest rates than comparable unconnected firms, they are

\footnotetext{
${ }^{23}$ Interestingly, however, even in the US before the significant strengthening of investor protection in the 1930s, firms under the influence of the JP Morgan Bank appeared to have traded at a premium (de Long, 1991).
} 
less likely to repay (Faccio, 2006; Khwaja and Mian, 2004; Chiu and Joh, 2004). Indeed, government ownership of banks is associated with lower growth and less financial development (LaPorta, Shleifer and Vishny, 2002).

A recent literature has been able to measure the value of political connections. A carefully constructed study by Fisman (2001) of the Suharto regime in Indonesia assesses how much the political connections of entrenched elites are worth. Fisman exploits variance over time in Suharto's health and across firms in terms of their political connection to the Suharto government in order to estimate the independent impact of political connections to stock returns. Every time rumors spread regarding Suharto's health, share prices fell for all firms, the more so, the more serious the rumor. Critically, shares in politically connected firms fell more than for the mean company. Over $20 \%$ of a politically connected firm's value appears to have derived from its political connections. Empirical work on other countries has produced qualitatively similar results. Claessens, Feijen and Laeven (2006) show how firms in Brazil connected to political candidates exhibit excess returns upon their election, and are able subsequently to access more credit. Khwaja and Mian (2005) study how political connections markedly increases financial access for Pakistani firms. They identify connected firms as those with a board member who runs for political office, and find that connected loans are 45 percent larger and carry average interest rates, although they have 50 percent higher default percentage. Moreover, only government-owned banks afford politically connected firms such preferential treatment. Finally, they find that political rents increase with the strength of the firm's politicians and whether he or his party is in power. They estimate that the economy-wide costs of the rents afforded to politically connected firms through government-owned banks costs up to 2 percent of GDP per year.

Faccio (2006) addresses the issue of politically connected firms across countries. She codes politically connected firms in a database of over 20,000 publicly-traded firms in 47 countries. Only a small fraction of firms (2.7\%) in her sample meet the criteria for being politically connected, namely being visibly connected to a minister or a member of 
parliament; moreover, this number is tightly clustered around the sample mean. ${ }^{24}$ Yet such firms tend to cluster in a subset of countries in which weak limits on the authority and discretion of government officials allows for high degrees of corruption. These include Indonesia (where 22 percent of publicly-traded firms are politically connected), Russia (20 percent), Malaysia (20 percent), Thailand (15 percent), and Italy (10 percent). All of these outliers are countries in which there is broad electoral representation, but in which public officials operate with a high degree of authority and discretion. Indeed, while Italy offers reliable protection of citizen rights, it is also a known outlier on corruption scales among developed countries.

Faccio, Masulis, and McConnell (2005) look at the impact of political connections on preferential access to government bailouts after a shock in a sample of 450 politically connected listed firms from 35 countries over the period 1997 through 2002. They find that politically connected firms are significantly more likely to be bailed out than similar non-connected firms. Remarkably, among all bailed out firms, those that are politically-connected exhibit significantly worse financial performance over the following two years. This evidence suggests that political connections distort the allocation of capital.

A distinctive sign of regulatory bias towards inside capital is when group owners are able to control considerable resources without having to actually risk much of their own capital, e.g. via pyramid structures and cross-holdings between firms. In more accountable systems, legal restrictions on the degree of separation of control rights from cash flow rights, often introduced as listing rules in the major stock markets, restrict the span of control and the resulting extreme agency problems. Claessens, Djankov, and Lang (2000) show that over two-thirds of East Asian firms are controlled by a single shareholder, usually with relatively small stakes in their cash-flow rights. Claessens, Djankov, Fan, and Lang (2002) study over 1,300 publicly traded corporations across eight East Asian countries and conclude that relative firm value increases with the share of cash flow rights in the hands of the largest shareholder. Almeida and Wolfenzon (2006) model how group ownership structures are especially attractive when capital

\footnotetext{
${ }^{24} \mathrm{~A}$ firm is identified as being politically connected if at least one of its large shareholders (anyone controlling at least 10 percent of voting shares) or one of its top directors (CEO, president, vice president, or secretary) is a member of parliament, a minister or is closely related to a top politicians or party.
} 
markets are inefficient, as the ability to use internal capital markets across group firms provide advantages over competitors. A broader review of the evidence on entrenched business groups on growth is offered by Morck, Wolfenzon, and Yeung (2006), who conclude that the misallocation of resources from narrow control over finance has large economic effects. Durnev, Li, Morck, and Yeung (2004) argue that pyramidal structures suppress transparency and limit the informativeness of share prices, causing them to move in a highly correlated fashion. They find that stock return asyncronicity is highly correlated with slower growth, and argue that uninformative prices are of scant use in allocating capital.

Acemoglu (2005) and Caselli and Gennaioli (2005) consider the consequences of family-based ownership structures, where control of the firm is passed down from one generation to the next. If the heir to a family firm has little managerial talent, dynastic management will reduce firm productivity. As family business groups often control vast portions of the economy in LDCs, dynastic management may contribute substantially to cross-country differences in productivity.

Bertrand, Johnson, Samphantharak, and Schoar (2005) test the negative effects of dynastic management on a data set of family trees and business groups for 100 of the largest business families in Thailand. They exploit variance in family size and number of sons as a measure of potential conflict after the death of the founder, as the result of non cooperative tunneling, and find that firm performance declines the more sons there are.

Morck, Yeung and Wolfenzon (2006) argue that some family business groups, faced with the issue of succession, may prefer to sell units to emerging managerial talent. Caselli and Gennaioli (2005) model the incentive to create better financial access so that those groups with the least talented children may be able to divest units to better owners. They conclude that legal reform aimed at improving access to finance may meet less entrenched opposition than entry deregulation.

\section{Section 3.2 Captured financial regulation}

We turn now to the case when political influence on the allocation of finance is indirect, resulting from distorted regulation favoring specific groups rather than via direct state control or concentrated bank ownership. This corresponds to a transition in the form 
of political influence from bribing to lobbying, thus from more personalized favors to biased norms indirectly favoring specific groups (Perotti and Vorage, 2008). While bribing is illegal in all countries, lobbying is admitted and institutionalized in many developed countries. While lobbying may also serve an useful informative function, opportunistic lobbying is likely to arise when increased public scrutiny on outright corruption induces a shift to influence choices which may be justified under reasons of public interest. Harstad and Svensson (2006) argue that the shift from bribing (bending the rules to favor someone) to lobbying (changing the rules permanently to favor them) occurs at a higher level of economic development, when more capital is sunk and thus ex post bribes become very expensive. This is consistent with the political access view, as long as capital accumulation takes place under broader political rights.

Arguably, the most important cost of captured regulation is the suppression of entry and competition. Entry is an important form of economic renewal and contributes to economic growth (e.g. Hause and Du Rietz, 1984; Johnson, McMillan and Woodruff, 2002). Competition ensures efficiency and encourages reallocation of resources to the better users or uses.

Lobbying may produce weak financial regulation and enforcement in order to limit access to finance for less established competitors. Denying them funding can be justified with prudential reasons which are hard to disprove, so it is also a stealthy barrier (Rajan and Zingales, 2003). Financial barriers which deny fungible resources also hinder entrepreneurs to overcome other generic obstacles to entry or expansion.

An interesting natural experiment is offered in Gormley and Gopalan (2007), who study the response to a liberalization of IPO listings when India had to liberalize its financial system at a time of financial crisis. This relaxation resulted in a massive flow of public equity listings of over one thousand firms in a five year period, indicating that the ban held back a massive number of less established firms. They analyze the characteristics of these IPO firms relative to a sample of private firms that did not go public. The most surprising result is that, in contrast to the evidence from developed countries, the listing firms were smaller and younger than the average unlisted private firms. They also show that the IPO funded faster investment and sales growth rather than 
representing divestitures of owners. Finally, these firms were significantly less likely to be affiliated with a family business group.

Recent evidence corroborates the notion that autocratic regimes establish very high barriers to entry even outside the financial system. Djankov, La Porta, Lopez-deSilanes, and Shleifer (2002) show that entry costs are very high in developing economies, and particularly so in corrupt countries. Haber, Razo, and Maurer (2003) document the existence of these barriers at the level of individual firms and industries in Mexico. Onerous requirements and regulations hindering production may be created to extract bribes (Shleifer and Vishny, 1993) and maintaining high rents. Fisman and SarriaAllende (2004) and Klapper, Laeven, and Rajan (2004) show that onerous barriers appear to reduce growth and entry in naturally high entry sectors and do not seem justified on reasons of public welfare. ${ }^{25}$

The evidence strongly suggests that financial barriers matter significantly. Financial underdevelopment and limited bank competition appear to be serious obstacles for new firm creation and economic growth (Rajan and Zingales, 1998; Beck, Levine and Loyaza, 2000; Black and Strahan, 2002).

A specific model of captured financial regulation, where access to finance is a critical mechanism through which competition is held back, is developed and tested empirically in Perotti and Volpin (2006). They model and test the notion of a causal relationship between political accountability, entry rates, and competition intensity. ${ }^{26}$ Wealthier agents who do not need much external finance for investment naturally form a lobby for weak enforcement of investor protection, to block access to funding for other entrants. Better political institutions should allow citizens to control opportunistic policies that benefit few producers. As lower entry reduces welfare, it requires higher political contributions ("bribes"). Thus greater political accountability, defined as the

\footnotetext{
${ }^{25}$ High financial barriers to entry in developing countries are puzzling in view of the evidence from micro credit of very high marginal profitability of small projects by the poor with no access to formal finance (Banerjee and Duflo, 2005; De Mel, McKenzie and Woodruff, 2006)

${ }^{26}$ A closely related paper is Bebchuk and Neeman (2005), who show how minority investor protection will be kept suboptimally low by lobbyists for insiders seeking to protect their control benefits. Their intuition is straightforward: insiders can use firm resources, while other investors have limited stakes and thus reduced incentives.
} 
shadow cost incurred by politicians by reducing welfare, induces lobbyists to accept more competition and higher entry. Analyzing the data used in the Rajan and Zingales (1998) study of the effect of financial development on industry growth, they find that entry rates and producer numbers are lower when investor protection is weak, particularly in sectors that are more dependent upon external finance. They next look at whether countries with more accountable political regimes have better investor protection. Unfortunately, it is hard to measure actual political accountability. Corruption is a very natural measure of the extent to which politicians can pursue self interested policies, yet for obvious reason it is not directly observable. So any indicator must rely on subjective evaluations, which are thus potentially endogenous to outcomes (Glaeser et al, 2004). Corruption measures are in fact extremely correlated with the logarithm of per capita income (Svensson, 2005). The same problem arises with other sensible proxies, such as the quality of contract enforcement. So, while proxies of democratic and contractual quality perform well in regressions for investor protection, they are no longer significant once a general control for institutional quality, such as GDP per capita, is introduced in the regression.

In order to get around this problem, Perotti and Volpin use a measure of access to information for voters, which is indispensable for scrutiny of public choices. Newspaper circulation turns out to be a very significant determinant of effective investor protection after controlling for per capita income and legal origin. Importantly, the effect of diffusion of the press is not due to differences in average education levels. State ownership of the press has a significant negative effect-a result that is consistent with the view that political institutions directly influence financial development.

This result is consistent with the recent literature on the impact of the media on economic outcomes. Both media diffusion and subjective accountability measures show huge variation among democracies. Media diffusion appears important for dispersed agents to monitor the actions of incumbent politicians, and therefore induces policies more responsive to citizens' actions (for a review, see Besley, Burgess and Prat, 2006). ${ }^{27}$ Media diffusion is of course correlated with subjective measures of its quality, such as

\footnotetext{
${ }^{27}$ As the lobbying power of special interest groups depends on what voters know, the media can be quite influential when low media costs and high literacy support a large market (Dyck, Moss and Zingales, 2005).
} 
press freedom, and with measures of political accountability in the Polity IV database. Interestingly, both are lower when the media is politically captured (Djankov et. al., 2001). This result suggests that accountability in a system which has embraced formal democratic rules depends on the degree of reliable information enjoyed by voters in order to be able to subject to scrutiny the policy choices of politicians.

This is analogous to the notion in corporate governance that diffusion of information via disclosure, combined with standards for investor protection, enables private monitoring and is particularly effective at constraining abuse (La Porta, Lopez de Silanes and Shleifer, 2006). Greater accountability appears to limit political interference, thereby reducing entry costs, allowing more reliable contracting and providing broader access to finance. Interestingly, while the size of domestic capital markets contributes to explain entry, it is no longer significant once controls are introduced for effective investor protection. Thus individual access to finance is more critical for new entry than the general state of financial markets.

\section{Section 3.3 The Political Roots of Financial Instability}

The political access approach of this survey leads to a natural conjecture on the critical role for political institutions on financial instability. Experiences with financial crises are potentially very informative about the allocation of political rights and privileges. If poor institutions fail to restrain opportunistic actions by bank or firm managers and owners, they will increase the chance of crises or worsen their consequences. Indeed, there is strong evidence that poor political institutions appear to explain macroeconomic instability better than actual macroeconomic policies (Acemoglu et al, 2003). Can political capture of regulation also explain variation in financial fragility, defined as the degree of financial default in response to an external shock? Can it also explain the distribution of financial losses?

On average, reforms targeted at expanding capital markets are associated with an immediate impulse to investment and growth (Henry, 2003). Bertrand, Schoar and Thesmar (2004) show how the French banking liberalization in the 1980s improved the allocation of capital while broadening access to finance. Yet, liberalizing reforms have had a mixed success in many developing countries. Often an expansion in credit and 
investment has been followed by severe crises after external shocks (as in Mexico, South East Asia, and Russia). Such crises are often coupled with sharp currency devaluations. They are also associated with corporate defaults and large losses for investors and taxpayers. They contribute to deep recessions and large scale exit. (Clarke, Cull, and Shirley 2005; Haber 2005.)

Sharp banking crises are more likely in countries with worse institutions or poor transparency (Demirguc-Kunt and Detragiache, 1998). Bekaert, Harvey and Lundblad (2004, 2006) show that financial liberalization is more likely to produce instability in countries with low quality political institutions and in countries with poor investor protection. This suggests that better institutions are necessary for a country to benefit from more open financial markets. Caballero and Khrishnamurty (2003) show that firms in countries with poor investor protection and a binding international collateral constraint will not adequately precaution against adverse shocks, increasing the severity of those shocks.

A clear effect of weak investor protection is that less established firms (i.e. newer, less capitalized producers) are unable to raise additional funding after external shocks, forcing them in bankruptcy. Yet the specific financial fragility for smaller producers may depend on the degree of capture of financial regulation by incumbent interest groups, which would benefit from exit for less established firms. An alternative view would be that shocks have a cleansing effect, inducing exit of marginal producers (Caballero 2006). How can these views be distinguished?

There is increasing evidence from cross country and cross industry studies that the costs of widespread default are very unequally distributed. Kroszner, Laeven, and Klingebiel (forthcoming) find that financially dependent sectors grow faster in normal times but are hit harder at time of financial crises. However, this effect is much more pronounced in sectors with a larger number of small firms. Desai, Foley and Forbes (2007) show that after large currency devaluations, smaller exporting firms are unable to access finance to fund their now more competitive products, unlike the more established firms. Other evidence shows that precisely those sectors that depend more on external finance are most hurt in banking crises (Dellariccia, Detragiache and Rajan, 2007). While this may simply reflect a reduction in bank loan supply, the effect is not uniform across 
all firms: sectors with more small firms are particularly hard hit, especially in developing countries.

The capture of investor protection supporting access to refinancing is modeled in Feijen and Perotti (2006), as the outcome of lobbying by more established producers. In countries with low political accountability, only established firms will access financing after a shock, as the more leveraged producers are forced to exit. ${ }^{28}$ Feijen and Perotti (2006) show that exit rates during banking crises—especially for finance-dependent young firms - are abnormally high in countries with more corrupt political institutions. The effect is robust to controlling for GDP per capita, legal origin and for measures of aggregate financial development, suggesting that corruption affects the distribution of finance at a time when it is really critical for firm survival. Excess exit rates do not appear to be due to exogenous sources of agency costs, the size of the external shock, industry competition level, or openness to imports. Profit rates of surviving firms after a shock are significantly higher in corrupt countries. ${ }^{29}$ These results reinforce the notion that countries with less accountability have less reliable access to finance, especially for less established firms.

Poor investor protection associated with influential company insiders appears to have consequences at the macroeconomic level. Johnson, Boone, Breach, and Friedman (2000) focus on the implications of weak corporate governance for real exchange rate depreciation and stock market performance in 25 emerging economies during the Asian Financial Crisis of 1997-98. They find that the drop in exchange rates and stock markets is better explained by institutions of corporate governance than by conventional explanations of inappropriate macroeconomic policies, such as exchange rate policy, government borrowing or exuberant lending by international banks. They hypothesize that weak corporate governance allowed controlling stockholders to transfer assets out of

\footnotetext{
${ }^{28}$ Interestingly, more volatile shocks leads to more fragility not only because they cause larger losses, but because they reduce profitability, and thus increases the incentive to lobby to protect established rents.

${ }^{29}$ A significant level of post crisis profitability tin these countries is particularly surprising, as reported profits are likely to be noisy and downward biased in more corrupt countries, if tax evasion is easier (as suggested in Dyck and Zingales, 2007) and if it tends to worsen in a crisis
} 
listed companies once the shock reduced their incentive to maintain some access to financial markets. ${ }^{30}$

\footnotetext{
${ }^{30}$ Much anecdotal evidence indicates that many owners of established companies which defaulted during the Asian crises managed to avoid loss of control over important assets. The visible exception appears to be Korea, in which public opinion mobilized to condemn overborrowing and default in chaebol group firms, and led to serious reforms in corporate governance rules.
} 


\section{Section 4}

\section{Political Choices in Democracies}

In the political economy approach to financial development the degree of regulatory capture by the economic elite is a function of political accountability. Thus a natural extrapolation would be that broader political rights necessarily lead to broader and deeper financial development. Bordo and Rousseau (2006) analyze a small panel of countries over the period 1880-1997, and find a strong, independent effect of proportional representation, frequent elections, female suffrage, and political stability on the size of the financial sector. The result, while qualified because of the small cross country sample, is robust to controlling for initial per capita income and legal origin.

Yet as democracy progressively deepened over the nineteenth and twentieth centuries, financial development and breadth of access did not always exhibit steady progress. The variation in financial depth, diffusion of shareholdings, and concentration of control, while possibly decreased in recent years, remains remarkable even among democracies (La Porta et al., 1997, 1998). While democracies tend to generate financial systems that distribute capital more broadly than autocracies, a democratic majority does not necessarily seek to achieve the broadest degree of financial development possible.

One reason for this outcome is that democratic political systems can give rise to coalitions of organized labor and inside capital who see it in their mutual interest to block broad access to capital from new firms who would dissipate their rents. A novel theory literature offers a new foundation for the classic distinction between shareholder and stakeholder capitalist systems, traditionally based on unexplained differences in social preferences. ${ }^{31}$ A political explanation seems a natural candidate to account for the negative correlation between the degree of investor and labor protection across countries. $^{32}$ The additional benefit of explicit theoretical models is that they may also help interpret structural changes in financial structure across democracies, and in

\footnotetext{
${ }^{31}$ The Variety of Capitalism (VOC) approach has systematically identified a clustering of economic policies and institutions which differentiate corporatist and market economies (Soskice and Hall, 2001).

32 The normative appreach by Allen and Gale (2003) show that bank centered systems may be preferred because they absorb intertemporal risk better than market based systems, which are best at intratemporal risk sharing.
} 
particular the Great Reversal identified by Rajan and Zingales (2003) for a large number of developed financial systems in the interwar period.

Modeling democratic choice may take two approaches. In the first approach, a democratic majority requires a coalition among predefined multiple constituencies, which hold different views on financial structure. ${ }^{33}$ In the second approach, voters differ only by their endowment, and the will of a majority depends on the view of the median voter.

The seminal work by Pagano and Volpin (2005) exemplifies the first approach. It is intermediate between lobbying and democratic voting models, as it focuses on political alliances between interest groups, some of which are numerically modest but still able to influence political choices. ${ }^{34}$ They illustrate a political equilibrium among three social groups, namely inside capital (controlling shareholders), outside capital (minority investors) and inside labor (workers). Pagano and Volpin show how poor minority investor protection may be the result of political incentives to cater to workers and inside investors, who seek to protect their labor and control rents against minority investors. In particular, proportional voting pushes political parties to cater more to the preferences of social groups with homogeneous preferences, such as controlling shareholders and employees. Under a majoritarian system, by contrast, there is keen competition for the votes of pivotal districts where no focused interest group is dominant. Therefore dispersed investors may be pivotal in choosing elected politicians in a majoritarian system. Compellingly, Pagano and Volpin provide evidence of a negative correlation between minority investor protection and labor protection laws, and document that in proportional representation systems minority shareholders get poorer protection and employees get stronger protection than in majoritarian ones. ${ }^{35}$

\footnotetext{
${ }^{33}$ Even if full financial development were efficient, the efficient solution may not be achieved either because of limited political commitmnet, or because markets are incomplete.

${ }^{34}$ Supporters of this approach (e.g. Persson and Tabellini, 2003) argue that economic preferences by themselves cannot explain policies, as in a democracy power requires alliances between various groups. If interests are highly differentiated, electoral structure (majoritarian versus proportional systems) shape the way preferences are aggregated, and thus determine major political choices.

${ }^{35}$ This is consistent with evidence that the electoral system affects the orientation of government policies. Recent evidence points to a higher degree of redistributive public spending in proportional versus majoritarian systems (Persson and Tabellini 2003).
} 
This approach highlights the importance of the electoral structure to explain the traditional classification of stakeholder or shareholder oriented systems. ${ }^{36}$ It does not lend itself to explain variation in financial development over time, as changes in electoral systems are rare. We turn to a general democratic voting model where only a few voters qualify as holding inside capital therefore have limited political power by themselves. In general all voters have a mixed identity as investors and workers. This approach allows for the study of the effects of large economic shocks on political preferences for a democratic majority.

Poor individuals with few financial holdings in general, prefer high labor rents and a corporate governance system centers around bank rather than market governance, since this reduces risk exposure for labor income (Perotti and von Thadden, 2006) . They may prefer accordingly a financial system dominated by banks which share their aversion to risk. ${ }^{37}$ In contrast, richer individuals tend to vote for low labor rents and (dispersed) equity control. In this context, the financial participation of the middle class is critical. If the median voter has a sufficient financial stake, a majority will support dispersed equity control, which results in riskier but more profitable investment at the cost of greater labor risk-bearing. In contrast, when financial wealth is concentrated, a political majority has more firm-specific human capital than financial capital, and therefore opposes rights for market investors. ${ }^{38}$ The attitude of a political majority over competition will be similarly affected by the relative interest in protecting inside labor rents over financial returns.

Their approach predicts a clustering of governance and labor laws consistent with the evidence. Still, some external variation is indispensable to test this "political preference hypothesis”.

\footnotetext{
${ }^{36}$ For a rich classification of financial systems as a function of possible alliances among different stakeholder groups, see Gourevitch and Shinn (2005).

${ }^{37}$ A simpler explanation for a dominant role of banks when security laws are poorly enforced is that banks are in a better position to extract repayment from insiders than dispersed bond or share holders (Modigliani and Perotti, 2000).

${ }^{38}$ Biais and Mariotti (2003) investigate the related issue of political choice over bankruptcy rules. Tough creditor protection reduces competition and thus favor more established producers. They also examine explicitly the implications for labor interests.
} 


\section{The Great Reversals}

A major challenge is the need to explain the remarkable rise and decline of public capital markets in Continental Europe and Japan in the first half of the XX century, documented first in Rajan and Zingales (2003). They show that in 1913 civil law countries such as France, Belgium and Austria were more financially developed than the US or the average common law economies. In subsequent decades, capital markets in many European countries (and Japan) shrank dramatically, while the governance mode shifted towards bank, family or state control. In contrast, other democracies experienced further market development, in part via regulation which strengthened minority investor rights. While the 1913 data has been criticized, it is clear that at that time there was no advantage in financial development for common law countries. Some factor other than legal origin must have contributed to broad changes in financial structure in a subset of democratic countries.

Rajan and Zingales argue that these reversals reflected a change in the ability of special interest lobbies to capture financial regulation as a result of the shock of the Great Depression. Nationalistic feelings caused by economic insecurity in the face of a massive recession were hijacked by domestic incumbents. The crisis led to drastic trade barriers which weakened the principle of free competition and entry, and strengthened the political power of more established firms. This explanation is consistent with a general increase in industrial concentration which favored incumbents.

The economic and trade collapse was common to all countries, and trade barriers were erected overall in response to similar actions by others. Yet the Great Depression led some countries to limit radically the role of markets (some countries chose to restrict not just economic but even political freedoms), and adopt corporatist policies protecting inside labor, while others preserved and even strenghtened the role of product and financial market competition. Some specific explanation is needed to explain this variation in the shift towards more managed competition and corporatist policies across a subset of similarly democratic countries.

Rajan and Zingales (2003) speculate that in civil law countries, the state had by design a more centralized grip on legislation, and regulation was more easily captured by special interests during the Great Depression. This argument points to a structural role for 
legal origins in influencing politics. It does not explain the large outliers among civil law countries, such as the Netherlands, Switzerland, Sweden and Denmark, which maintained broad financial markets throughout the period, nor their marked historical difference from very similar neighbors (Belgium, Austria and Finland).

Is there a political explanation for this variation in choices across democracies ? In the democratic voting model by Perotti and von Thadden (2006), a major shock which imoverishes the middle class may cause a shift in political support against investor protection and towards corporatist policies, concentrated ownership and bank finance.

Perotti and von Thadden (2006) argue that large inflationary shocks after WW1 which hit some (but not all) Continental European countries reduced the financial stake of their middle class, causing a seismic political shift. Prior to WW1, Europe had a long period of peace and price stability. Although there were market crashes and failed banks, nominal contracts were safe, where long term contracts and debentures (even perpetuities) were common. WW1 developed unexpectedly into a major onslaught with devastating damage. Government spending rose sharply during the war. After the war, countries heavily damaged by war, faced intense pressure for urgent repairs, war reparations, widow and veteran assistance. Additional pressure for social spending socialist movements popular among demobilized troops. In many cases monetary printing was the only short-term solution. Prices jumped dramatically in France, Italy and Belgium, while Austria and Germany experienced dramatic hyperinflations. Critically, the distribution of these price shocks appears independent of legal or political institutions at the time, and is largely driven by war damage (Perotti and Schwienbacher, 2007). ${ }^{39}$

While all social classes suffered, the devaluation of long-term nominal assets hit hard the financial holdings of the pivotal middle and lower middle class. ${ }^{40}$ Similar price

\footnotetext{
${ }^{39}$ A related argument has been provided by Lindner (1994), who argued that the Great War forced elites to open up the political system and increase state social program as compensation for the high cost born by the mobilized masses. In a similar vein, Roe (2006) attributes the reversal to a rise in ideological polarization between labor and corporate owners as a result of war. While his interpretation implies a shift in beliefs rather than in economic interests, the two arguments are closely related. From an economist's point of view, it seems natural to assume that ideological preferences adapt to economic interests.

${ }^{40}$ A prominent German economist wrote in 1924 that "there has been an appropriation of property in few but strong hands. The financial property of the middle class .. has been destroyed. This appropriation refers mainly to big business. Small and medium-size entrepreneurs have not been expropriated, but have been brought more strongly under the influence of big business. Because of this, the distribution of wealth has become much more unequal" (Eulenburg, 1924).
} 
shocks devastated other countries affected by civil war, such as Greece, Spain and Finland, and Japan with the 1946 hyperinflation. After some recovery in the late twenties, the Great Depression created immense pressure for social and economics reforms.

Countries with impoverished middle classes shifted support away from financial markets with dispersed shareholders towards a more corporatist system of financial allocation, with a central role for large owners, banks and the state. Mass support for a suppression of economic freedom and a shift of corporate control to the state or to financial institutions, as the average citizen sought more stabilizing governance structures and greater social insurance at the cost of less free markets. The result was a greater politicization of control, market suppression, and the emergence of stronger social insurance programs typical of a corporatist economy.

The UK, the Netherlands, Switzerland, Australia, Canada, parts of Scandinavia (except Finland) and the US escaped high inflation, and accordingly maintained more support for security investors. In fact, government of the US Liberty Bonds were broadly promoted financial participation, increasing the diffusion of holdings of financial securities from 30 thousand to 20 million households.

The financial orientation of the middle class had a major effect in determining the political response to massive unemployment during the Great Depression. In all countries it led to more generous social programs, and in particular, it induced the creation of more generous and inclusive pension systems, starting with Social Security Act of 1935 in the US. Yet this did not result everywhere to the same sharp increase in state control or weaker financial markets. Countries with a market friendly orientation actually strengthened investor protection, with the US establishing the Securities and Exchange Commission in 1933 and limiting banks' role in corporate control with the Glass Steagall Act. In contrast, an economically and financially enfeebled middle class in continental Europe sought a more corporatist governance structure, stronger labor protection, greater politicization of control, a reduced role for markets, and more social insurance and welfare.

Perotti and Schwienbacher (2006) explore whether these wealth distribution shocks may explain a dimension of financial systems which has arguably the broadest political significance, namely the structure of its pension system. The cross country 
variation in pension funding dwarfs the variation in financial development, even among developed countries. Why was the government entrusted with retirement in some countries, while elsewhere private funding was preferred? Why does Finland have so little private pensions in comparison to Denmark or Sweden, or Belgium in comparison to the Netherlands, or Switzerland so much relative to Austria? The financing of universal retirement programs is politically sensitive, as they cover most individuals, have significant fiscal benefits, and dominate old age income for most citizens. The historical choice of pension funding determines the allocation of enormous financial savings, on a scale capable of shaping financial participation and public attitudes to capital markets. But what explains the initial assignment of pension contributions between the state and the private sector?

Most redistributive shocks took place before the initial design of national pension systems in developed democracies. Which took place between the late 1930s and the early 1950. The evidence in Perotti and Schwienbacher suggests that countries which experienced massive price shocks chose overwhelmingly for a (predominantly) state funded pension system. ${ }^{41}$ The effect is economically and statistically very significant: a large shock is associated with a lower stock of private retirement assets equal to $58 \%$ of GDP. In contrast, the degree of private pension funding is not correlated with legal origins, demographics, historical financial orientation, electoral structure or cultural institutions such as religion once the price shocks are accounted for.

Political shocks may also account for the variation in concentration of ownership documented in La Porta et al (1998). The emergence of corporatism was associated to increased concentration of ownership in most countries, very visibly in Sweden and Italy (Hogfeldt, 2003; Aganin and Volpin, 2003). Increasing concentration of control emerged as political forces weakened the role of dispersed financial investors. The emerging corporatist system favored weakening minority protection and sought political influence on corporate decisions by negotiating with large owners or dominant bankers. Undiversified large owners could be trusted to take a more conservative approach than markets, just as banks did.

\footnotetext{
${ }^{41}$ There was no direct effect of high inflation due to losses on pre existing pension fund reserves, as preDepression pension claims were very modest, and no affected country switched to PAYG immediately after experiencing the shock.
} 
Roe (2003) agrees that the shift in corporate governance resulted from war shocks in some countries, but was the result of private rather than public policy choices. He argues that war devastation led to a rise in ideological polarization between labor and corporate owners. In response to socialist activism, companies required more active and engaged shareholders with controlling stakes to counter the influence of organized labor. Clearly, such an increase in the concentration of control had to be accepted by the political system. ${ }^{42}$ Thus shocks may have led to ideological hostility to capital markets, shifting not just economic interests but also beliefs, although ideology may have simply followed economic interest. Perotti and Schwienbacher show that citizens in countries hit by major price jumps exhibit higher uncertainty aversion. Uncertainty aversion appears to be negatively correlated with the stocks of private pension assets, but does not reduce the effect as price shocks.

Once the pension system directs retirement savings to the state and creates a political channel for co-insurance, this historical orientation towards private security markets naturally become self-reinforcing. A population which holds few financial claims on the private sector will not support protection of dispersed investors, thus discouraging private investment in securities. This in turn undermines political support for minority investor rights.

Wealth allocation may even be exploited politically to help electoral outcomes and support for preferred policies. Aghion and Bolton (1990), offered an early theoretical contribution to this literature motivated by Reagan's deficit spending politics. They show how a right wing party seeking reelection may designs debt policies to align the preferences of the median class voters against redistributive macroeconomic policies.

Biais and Perotti (2002) apply this Machiavellian logic to privatization policy in a democracy. Since state control enables labor and other insider interests to be favored directly, less wealthy voters may resist privatization to favor larger rents to SOE labor funded by taxation. In fact, in an unequal society the median voter may never choose to elect a privatizing government unless the inefficiency of state control passes some threshold. At the point when the middle class feels excessively burdened, a right wing

\footnotetext{
${ }^{42}$ The country evidence described in Rajan and Zingales (2003a) suggests that corporate elites thrived better in corporatist systems thanks to political connections.
} 
government may be elected with a mandate to privatize. Reelection policy would involve a strategic privatization program allocating enough shares to the median class induce a political shift away from left wing parties whose policy would reduce the values of shareholdings. They show that to induce middle class voters to buy enough shares to shift political preferences, strategic rationing and underpricing should increase with wealth inequality. Interestingly, the evidence is that right wing privatizing governments under price more and target more individual investors, and that underpricing is increasing in income inequality (Megginson et al, ).

There have been several examples of conservative governments which deliberately pursued a more diffused distribution of ownership to counter socialist or populist opposition. ${ }^{43}$ An interesting early example was Japan after WW2. After the US military administration seized control over shares in large companies from the zaibatsu owners, accused of collaborationism with the military, they proceeded to a free distribution of shares among the population. ${ }^{44}$ Other large-scale episodes of ownership distribution were the Thatcher and Chirac privatization programs, the Chilean privatization program, and voucher schemes in Russia and the Czech Republic. In all these programs with the exception of Russia, various constraints or incentives were introduced to avoid rapid resale ahead of elections, ranging from direct contribution of shares to pension funds (Chile), delay on distributing shares until after the election (Czech Republic), and financial incentives (UK and France in 1986-1987).

These models rely on the argument that financial structure is shaped by the economic and financial interests of the middle class. Yet for specific policies and historical events to leave a persistent effect, there must be forces which reinforce their effect overtime. One such argument is offered in Pagano and Volpin (2006). Better investor protection induces companies to issue more equity and thereby leads to a broader

\footnotetext{
${ }^{43}$ Privatization may also be captured, in which case insiders reaped more of the gains, as it has been often the experience within Latin America and many transition economies. This had repercussions on public support for privatization and reform in Latin America (Birsdall and Nellis, 2002). In Russia, privatization of valuable firms at low prices and asset stripping by managers has led to even higher inequality than before (Perotti, 2002), and has certainly contributed to decrease political support for a market economy.

${ }^{44}$ Most Japanese, impoverished by the war, sold their shares rapidly, not unlike Russian workers after mass privatization in the early 1990s. Bank-led consortia based on crossholdings, or keiretsu (Berglof and Perotti, 1995) led to a more concentrated ownership structure aimed at corporatist policies more consistent with political preferences.
} 
stock market and more liquidity, which expands the shareholder base and increases support for shareholder protection. Similarly poor investor protection may be self reinforced, for instance via a choice for state funding of pensions. They offer evidence of such a virtuous cycle in equity issuance in recent years in Europe, confirmed by increasing political acceptance of foreign takeovers.

Median voter models in this section share the assumption that voters choose directly policies and laws. This is a strong assumption even in countries with strong mechanisms to uphold accountability. Public scrutiny and intervention in government decisions are hindered by limited information and coordination problems. Yet democratic voting models are useful benchmarks to define what policies would be favored by voters as accountability increases. Their relevance is arguably greatest in explaining choices made at times of crises or distress, when voter attention on financial issues is high and coordination problems among citizens less relevant.

\section{Conclusion}

Political choices deeply affect the development and operations of the financial system. This review has identified three political constraints on financial development: autocratic opportunism, oligopolistic capture and democratic corporatism.

Early contributions had identified limited government as a precondition for reliable property rights and legal enforcement of contracts (North and Weingast, 1989). The literature on political determinants of financial structure is still fairly novel (see Pagano and Volpin (2001) for an early survey), but has had a major impact on the literature on comparative financial systems. The legal origin literature (LaPorta et al, 1997, 1998) has moved research beyond the conventional wisdom on the "continental European/Japan vs. the Anglo-Saxon model”. Political economy models offer further insight in complementary interpretations, identify if the role of dominant economic elites in holding back financial development (Rajan and Zingales, 2003), and interpreting the variation in financial structure across countries in terms of accountable political institutions. 
A second and distinct contribution of a political economy approach is its promise in explaining financial evolution, in particular structural breaks. Historical political shifts have been so far mostly interpreted as cultural shifts of which Roe represents the most updated effort (200?). Ideology changes are clearly endogenous, as beliefs seem to change as circumstances change. They may simply reflect underlying changes in the balance of political power, as in Rajan and Zingales (2003), or self reinforcing shifts in economic preferences by the pivotal middle class, as in Perotti and von Thadden (2006).

A particular reason for the relevance of the political broadening approach to financial development is that it describes a process that is taking place in many developing countries nowadays, and conditions the ability of financial markets to operate efficiently. The approach may also shed more light on persistent reforms aimed at market development and broader access. 


\section{References}

Acemoglu, Daron, Philippe Aghion and Fabrizio Zilibotti, Vertical Integration and Distance to Frontier, Journal of the European Economic Association 1, 2-3, pp. 630-38 (2002).

Acemoglu, Daron. Forthcoming. “Oligarchic vs. Democratic Societies.” Journal of the European Economic Association.

Acemoglu, Daron, and Simon Johnson. 2005. “Unbundling Institutions.” Journal of Political Economy, 113: 949-995.

Acemoglu, Daron, Simon Johnson, and James Robinson. 2001. “The Colonial Origins of Comparative Development: An Empirical Investigation.” American Economic Review, 91(5): 1369-1401.

Acemoglu, Daron, Simon Johnson, and James Robinson. 2002. "Reversal of Fortune: Geography and Institutions in the Making of the Modern World Income Distribution.” Quarterly Journal of Economics 117(4): 1231-1294.

Acemoglu, Daron, Simon Johnson, and James A. Robinson. 2005. "Institutions as the Fundamental Cause of Long-Run Growth.” In Handbook of Economic Growth. Vol. 1A, ed. Philippe Aghion and Steven Durlauf, 285-472. The Netherlands: Elsevier Science.

Acemoglu, Daron, Simon Johnson, James Robinson and Yunyong Thaicharoen. 2003. "Institutional Causes, Macroeconomic Symptoms: Volatility, Crises and Growth.” Journal of Monetary Economics, 50: 49-123.

Acemoglu, Daron, and James A. Robinson. 2006. Economic Origins of Dictatorship and Democracy. New York: Cambridge University Press.

Aganin, Alexander, and Paolo Volpin. 2005 “History of corporate ownership in Italy.” In The History of Corporate Governance Around the World, ed. Randall Morck, 325 - 361. Chicago: The University of Chicago Press.

Aghion, Philippe, and Patrick Bolton. 1990. “Government Domestic Debt and the Risk of Default: A Political-Economic Model of the Strategic Role of Debt.” In Public Debt Management: Theory and History, ed. Rudiger Dornbusch and Mario Draghi, 315-345. Cambridge: Cambridge Economic Press.

Allen, Franklin, and Douglas Gale. 2003. Comparative Financial Systems. Cambridge: MIT Press

Almeida, Heitor, and Daniel Wolfenzon. 2006. "A Theory of Pyramidal Ownership and Family Business Groups.” Journal of Finance, 61(6): 2637-2681.

Almeida, Heitor, and Daniel Wolfenzon. 2006. "Should Business Groups Be Dismantled? The Equilibrium Costs of Efficient Internal Capital Markets.” Journal of Financial Economics, 79(1): 99-144.

Anan’ich, Boris. 1999. "State Power and Finance in Russia, 1802-1917: The Credit Office of the Finance Ministry and Government Control over Credit Institutions.” In The State, the Financial System, and Economic Modernization, ed. Richard Sylla, Richard Tilly, and Gabriel Tortella, 210-223. Cambridge: Cambridge University Press.

Banerjee, Abhijit and Esther Duflo. 2005. “Growth Theory Through the Lens of Development Economics.” In Handbook of Economic Growth. Vol. 1A, ed. Philippe Aghion and Steven Durlauf, 473-552. The Netherlands: Elsevier Science.

Barth, James R., Gerard Caprio Jr., and Ross Levine. 2006. Rethinking Bank Regulation: Till Angels Govern. Cambridge: Cambridge University Press. 
Bebchuk, Lucian, and Zveski Neeman. 2006. A political model of investor protection.” Mimeo Harvard Law School.

Beck, Thorsten, Asli Demirguc-Kunt, Luc Laeven, and Ross Levine. 2005. "Finance, Firm Size, and Growth.” World Bank Working Paper No. 3485.

Beck, Thorsten, Asli Demirguc-Kunt, and Ross Levine. 2003. “Laws, Endowments and Finance.” Journal of Financial Economics, 70(2): 137-181.

Beck, Thorsten, Asli Demirguc-Kunt, and Ross Levine. 2003. "Law and Finance: Why Does Legal Origin Matter?” Journal of Comparative Economics, 31(4): 653-676.

Beck, Thorsten, Asli Demirgüç-Kunt and Vojislav Maksimovic. 2005. "Financial and Legal Constraints to Growth: Does Firm Size Matter?” Journal of Finance, 60(1): 137-177.

Beck, Thorsten, Asli Demirguc-Kunt, and Maria Soledad Martinez Peria. 2006. "Banking Services for Everyone? Barriers to Bank Access and Use Around the World.” World Bank Working Paper No. 4079.

Beck, Thorsten, Ross Levine and Norman Loayza. 2000. "Finance and the Sources of Growth.” Journal of Financial Economics, 58(1-2): 261-300.

Bekaert, Geert, Cam Harvey and Chris Lundblad. 2006. "Growth Volatility and Financial Liberalization.” Journal of International Money and Finance, 25: 370-403.

Benmelech, Efrain, and Tobias J. Moskowitz. 2005. "The Political Economy of Financial Regulation: Evidence from U.S. State Usury Laws in the $18^{\text {th }}$ and $19^{\text {th }}$ Century.” AFA 2007 Chicago Meetings Paper.

Berglof, Erik and Enrico Perotti. 2004. “The Governance Structure of the Japanese Keiretsu.” Journal of Financial Economics, 36(2): 259-284

Bertrand, Marianne, Simon Johnson, Krislert Samphantharak, and Antoinette Schoar. 2005. "Mixing Family with Business: A Study of Thai Business Groups and the Families Behind Them.” Unpublished, University of Chicago.

Bertrand, Marianne, Antoinette Schoar, and David Thesmar. 2003. "Banking Deregulation and Industry Structure: Evidence from the French Banking Reforms of 1985.” Mimeo University of Chicago Besley, Tomothy, Robin Burgess, and Andrea Prat. 2006. "Mass Media and Political Accountability." Mimeo London School of Economics.

Biais, Bruno, and Thomas Mariotti. 2003. “Credit, Wages and Bankruptcy Laws.” CEPR Discussion Paper No. 3996.

Biais, Bruno and Enrico Perotti. 2002. "Machiavellian Privatization.” American Economic Review, 92(1):240-258.

Birdsall, Nancy and John Nellis. 2002. "Winners and Losers: Assessing the Distributional Impact of Privatization.” Center for Global Development Working Paper No. 6.

Black, Sandra, and Philip Strahan. 2002. "Entrepreneurship and Bank Credit Availability.” Journal of Finance, 57: 2807-2833.

Bodenhorn, Howard. 1990. "Entry, Rivalry, and Free Banking in Antebellum America.” Review of Economics and Statistics, 72(4): 682-86. 
Bodenhorn, Howard. 2003. State Banking in Early America: A New Economic History. New York: Oxford University Press.

Bodenhorn, Howard. 2006. "Bank Chartering and Political Corruption in Antebellum New York: Free Banking as Reform.” In Corruption and Reform: Lessons from America's Economic History, ed. Edward Glaeser and Claudia Goldin, 231-57. Chicago: University of Chicago Press.

Bolton, Patrick, and Howard Rosenthal. 2002. "Political Intervention in Debt Contracts.” Journal of Political Economy 2 110(5): 1103-34

Bordo, Michael D., Hugh Rockoff, and Angela Redish. 1994. "The U.S. Banking System from a Northern Exposure: Stability Versus Efficiency.” The Journal of Economic History, 54(2): 325-341.

Bordo, Michael D., and Peter Rousseau. 2006. "Legal-Political Factors and the Historical Evolution of the Finance-Growth Link.” NBER Working Paper No. 12035.

Botero, Juan C., Simeon Djankov, Rafael La Porta., Florencio López de Silanes, and Andrei Shleifer. 2004. “The Regulation of Labor.” Quarterly Journal of Economics, 119(4): 1339-1382.

Broz, J. Lawrence, and Richard S. Grossman. 2004. "Paying for Privilege: The Political Economy of Bank of England Charters, 1694-1844.” Explorations in Economic History, 41 (1): 48-72.

Bueno de Mesquita, Bruce, Alastair Smith, Randolph M. Silverson, and James D. Morrow. 2003. The Logic of Political Survival. Cambridge: MIT Press.

Caballero, Ricardo J. and Arvind Krishnamurthy. 2000. "International and Domestic Collateral Constraints in a Model of Emerging Market Crises.” Journal of Monetary Economics, 48(3): 513-548.

Caballero, Ricardo, and Arvind Krishnamurty 2003. "Excessive Dollar Debt: Financial Development and Underinsurance.” Journal of Finance, 58(2): 867-893.

Caballero, Ricardo J. 2006. “Creative Destruction.” In The New Palgrave (forthcoming).

Calomiris, Charles W. and Eugene N. White. 1994. “The Origins of Federal Deposit . Insurance.” In The Regulated Economy: A Historical Approach to Political Economy, ed. Claudia Goldin and Gary D. Libecap, 145-188. Chicago: University of Chicago Press.

Caprio, Gerard, Luc Laeven, and Ross Levine. 2007. Forthcoming. “Bank Valuation and Governance.” Journal of Financial Intermediation.

Caselli, Francesco and Nicola Gennaioli. 2005. “Dynastic Management.” CEPR Discussion Paper No. 3767.

Cetorelli, Nicola, and Philip Strahan. 2006. "Finance as a barrier to entry: Bank competition and industry structure in US local markets.” Journal of Finance, 61: 437-61.

Chehabi, H. E., and Juan J. Linz. 1998. Sultanistic Regimes. Baltimore: Johns Hopkins University Press.

Chiu, Ming Ming, and Sung Wook Joh. 2004. "Loans to distressed firms: Political connections, related lending, business group affiliations and bank governance” Chinese University of Hong Kong mimeo

Claessens, Stijn. 2006. “Access to Financial Services: A Review of the Issues and Public Policy Objectives.” World Bank Research Observer, 21(2): 207-240.

Claessens, Stijn, Simeon Djankov, and Larry Lang. 2000. “The Separation of Ownership and Control in East Asian Corporations.” Journal of Financial Economics, 58: 81-112. 
Claessens, Stijn, Simeon Djankov, Joseph P. H. Fan, and Larry H. P. Lang. 2002. "Disentangling the Incentive and Entrenchment Effects of Large Shareholdings.” The Journal of Finance, 57(6): 2,741-71.

Claessens, Stijn, Erik Feijen and Luc Laeven. 2006. “Does Campaign Finance imply Political Favors?” Tinbergen Institute Discussion Paper no. 06-002/2.

Claessens, Stijn and Enrico Perotti, (2007). "Finance and inequality: channels and evidence.” Journal of Comparative Economics 35, 748-773

Clarke, George and Robert Cull. 2002. "Political and Economic Determinants of the Likelihood of Privatizing Argentine Public Banks.” Journal of Law and Economics, 45(1): 165-98.

Clarke, George, Robert Cull, and Mary Shirley. 2005. "Bank Privatization in Developing Countries: A Summary of Lessons and Findings.” Journal of Banking and Finance, 29 (8-9): 1905-30.

Cortes Conde, Roberto. 1999. "The Origins of Banking in Argentina.” In The State, the Financial System, and Economic Modernization, ed. Richard Sylla, Richard Tilly and Gabriel Tortella, 224-48. Cambridge: Cambridge University Press.

Cottrell, P.L., and Lucy Newton. 1999. "Banking Liberalization in England and Wales, 1826-1844.” In The State, the Financial System, and Economic Modernization, ed. Richard Sylla, Richard Tilly and Gabriel Tortella, 75-117. Cambridge: Cambridge University Press.

Cull, Robert, Stephen Haber, and Masami Imai. 2007. "Related Lending and Financial Development.” Stanford Center for International Development Working Paper.

Cull, Robert, and L.C. Xu. 2000. "Bureaucrats, State Banks, and the Efficiency of Credit Allocation: The Experience of Chinese State-Owned Enterprises.” Journal of Comparative Economics, 28(1): 1-31.

Davis, Lance E., and Robert E. Gallman. 2001. Evolving Financial Markets and International Capital Flows: Britain, the Americas, and Australia, 1865-1914. Cambridge: Cambridge University Press.

Dell’Ariccia, Giovanni, Enrica Detragiache, and Raghuram Rajan. 2005. “The Real Effect of Banking Crises.” IMF Working Papers 05/63.

De Mel, Suresh, David McKenzie, and Christopher Woodruff. 2006. "Returns to Capital in Microenterprises: Evidence from a Field Experiment.” Mimeo World Bank.

Demirguc-Kunt, Asli, and Enrica Detragiache. 1998. "Financial Liberalization and Financial Fragility.” Mimeo World Bank.

De Soto, Hernando. 2000. The Mystery of Capital: Why Capitalism Triumphs in the West and Fails Everywhere Else. New York: Bantam Books.

Desai, Mihir A., C. Fritz Foley, and Kirstin J. Forbes. Forthcoming. "Financial Constraints and Growth: Multinational and Local Firm Responses to Currency Crises.” Review of Financial Studies.

De Vries, Jan and Ad van der Woude. 1997. The First Modern Economy: Success, Failure, and Perseverance of the Dutch Economy, 1500-1815. Cambridge: Cambridge University Press.

Dinc, Serdar. 2004. "Government Ownership of Banks and Political Lending in Developing Countries.” Mimeo University of Michigan.

Dyck, Alexander, David Moss, and Luigi Zingales. 2004. “Media versus Special Interests.” Mimeo University of Toronto.

Dyck, Alexander and Luigi Zingales. 2004. "Private Benefits of Control: An International Comparison.” The Journal of Finance, 59(2): 537-600. 
Djankov, Simeon, Rafael LaPorta, Florencio Lopez-de-Silanes and Andrei Shleifer. 2002. "The Regulation of Entry." Quarterly Journal of Economics, 113: 1-37.

Djankov, Simeon, Rafael La Porta, Florencio Lopez-de-Silanes, and Andrei Shleifer. 2003a. "Courts.” Quarterly Journal of Economics, 118(2): 453-717.

Djankov, Simeon, Edward Glaeser, Rafael La Porta, Florencio Lopez de-Silanes, and Andrei Shleifer. 2003b. “The New Comparative Economics.” Journal of Comparative Economics, 31(4):595-619.

Djankov, Simeon, Caralee McLiesh, and Andrei Shleifer. Forthcoming. "Private Credit in 129 Countries.” Journal of Financial Economics.

Durnev, Art, Kan Li, Randall Morck, and Bernard Yeung. 2004. “Capital Markets and Capital Allocation: Implications for Economies in Transition.” Economies in Transition, 12(4): 593-634.

Easterly, William and Ross Levine. 2003. "Tropics, Germs, and Crops: How Endowments Influence Economic Development.” Journal of Monetary Economics, 50(1): 3-40.

Economopoulos, Andrew, and Heather O’Neill. 1995. "Bank entry during the Antebellum Period.” Journal of Money, Credit, and Banking, 27(4): 1071-85.

Engerman, Stanley L. 1970. "A Note on the Economic Consequences of the Second Bank of the United States.” The Journal of Political Economy, 78(4): 725-728.

Engerman, Stanley L., and Kenneth L. Sokoloff. 1997. "Factor Endowments, Institutions, and Differential Paths of Growth Among New World Economies: A View from Economic Historians of the United States." In How Latin America Fell Behind: Essays on the Economic Histories of Brazil and Mexico, 1800-1914, ed. Stephen Haber, 260-304. Stanford: Stanford University Press.

Engerman, Stanley L., and Kenneth L. Sokoloff. 2002. "Factor Endowments, Inequality, and Paths of Development Among New World Economies.” NBER Working Paper No. 9259.

Eulenburg, Franz. 1924. “Die sozialen Wirkungen der Währungsverhältnisse.” In Jahrbücher für Nationalökonomie und Statistik.” 122: 748-794.

Faccio, Mara. 2006. "Politically Connected Firms.” American Economic Review, 96(1): 369-86.

Faccio, Mara, Ronald Masulis, and John J. McConnell. 2005. "Political Connections and Corporate Bailouts.” Journal of Finance, 61(6): 2597-2635.

Feijen, Erik and Enrico Perotti. 2005. “The Political Economy of Financial Fragility.” Tinbergen Institute Discussion Paper No. 05-115/2.

Feijen, Erik and Enrico Perotti. 2006. “Exit During Crises.” University of Amsterdam Working paper.

Fisman, Raymond. 2001. "Estimating the Value of Political Connections.” The American Economic Review.” 91(4): 1095-1102.

Fisman, Raymond and Vanessa Love. 2005. "Patterns of Industrial Development Revisited: The Role of Finance.” World Bank Policy Research Working Paper No. 2877.

Fisman, Raymond and Virginia Sarria-Allende. 2004. "Regulation of Entry and the Distortion of Industrial Organization.” NBER Working Paper No. 10929.

Fogel, Kathy, Randall Morck, and Bernard Yeung. 2006. "Big Business Stability and Economic Growth; Is What is Good for General Motors Good for America?” NBER working paper 12394. 
Galor Oded, Omer Moav, and Dietrich Vollrath. 2006. "Inequality in Land Ownership, the Emergence of Human Capital Promoting Institutions and the Great Divergence.” Brown University working paper.

Gatell, Frank Otto. 1966. "Sober Second Thoughts on Van Buren, the Albany Regency, and the Wall Street Conspiracy.” The Journal of American History, 53(1): 19-40.

Gelfer, Stanislav and Enrico Perotti. 2001. "Red barons or robber barons? Governance and Investment in Russian financial-industrial groups.” European Economic Review, 45(9): 1601-1617.

Gennaioli, Nicola and Enrico Perotti. 2007. "Codification, Access to Justice and Contractual Innovation.” Mimeo University of Amsterdam.

Glaeser, Edward, and Andrei Shleifer. 2002. “Legal Origins.” Quarterly Journal of Economics, 117(4): 303-315.

Glaeser, Edward L., Jose Scheinkman and Andrei Shleifer. 2003. "The Injustice of Inequality.” Journal of Monetary Economics, 501(1): 199-222.

Glaeser, Edward L., Rafael La Porta, Florencio Lopez-de-Silanes, and Andrei Shleifer. 2004. "Do Institutions Cause Growth?” Journal of Economic Growth, 9(3): 271-303.

Gourevitch, Peter and James Shinn, 2005. Political Power and Corporate Control: the New Global Politics of Corporate Governance, Princeton: Princeton University Press.

Gordon, Roger and Wei Li. 2005. "Tax Structures in Developing Countries: Many Puzzles and a Possible Explanation.” NBER Working Paper No. 11267.

Gopalan, Radhakrishnan and Todd Gormely. 2007. "The Going Public Decision and the Role of Public Equity Markets in Emerging Economies.” Mimeo Washington University.

Gormely, Todd. 2006. "Banking Competition in Developing Countries: Does Foreign Bank Entry Improve Credit Access?” Mimeo Washington University.

Greenwood, Jeremy. and Boyan Jovanovic. 1990. "Financial Development, Growth, and the Distribution of Income.” Journal of Political Economy, 98(5): 1076-1107.

Greif, Avner. 1993. "Contract Enforceability and Economic Institutions in Early Trade: The Maghribi Traders’ Coalition.” American Economic Review, 83(3):525-48.

Grinath, Arthur, John Joseph Wallis, and Richard E. Sylla. 1997. , "Debt, Default, and Revenue Structure: The American State Debt Crisis in the Early 1840s,” National Bureau of Economic Research, Historical Working Paper.

Guiso Luigi, Paola Sapienza, and Luigi Zingales. 2004. “Does Local Financial Development Matter?” Quarterly Journal of Economics, 119 (3): 929-969.

Guiso Luigi, Paola Sapienza, and Luigi Zingales. 2004. "The Role of Social Capital in Financial Development.” American Economic Review, 94(3): 526-556.

Guiso, Luigi, Sapienza, Paola, and Luigi Zingales. 2006. “Cultural Biases in Economic Exchange.” NBER Working Paper No. 11005. 
Guiso Luigi, Paola Sapienza, and Luigi Zingales. Forthcoming. “Trusting the Stock Market.” Journal of Finance.

Haber, Stephen. 1991. "Industrial Concentration and the Capital Markets: A Comparative Study of Brazil, Mexico, and the United States, 1830-1930.” The Journal of Economic History, 51(3): 559-580.

Haber, Stephen. 1997. "Financial Markets and Industrial Development: A Comparative Study of Government Regulation, Financial Innovation, and Industrial Structure in Brazil and Mexico, 1840-1930." In How Latin America Fell Behind: Essays on the Economic Histories of Brazil and Mexico, 1800-1914, ed. Stephen Haber, 146-178. Pablo Alto: Stanford University Press.

Haber, Stephen. 1998. "The Efficiency Consequences of Institutional Change: Financial Market Regulation and Industrial Productivity Growth in Brazil, 1866-1934." In Latin America and the World Economy Since 1800, ed. John H. Coatsworth and Alan M. Taylor, 275-322. Cambridge: Harvard University David Rockefeller Center for Latin American Studies/Harvard University Press.

Haber, Stephen. 2003. "Banks, Financial Markets, and Industrial Development: Lessons from the Economic Histories of Brazil and Mexico.” In Macroeconomic Reform in Latin America: The Second Stage, ed. José Antonio Gonzalez, Vittorio Corbo, Anne O. Krueger, and Aaron Tornell, 259-293. Chicago: University of Chicago Press.

Haber, Stephen. 2005. “Mexico’s Experiments with Bank Privatization and Liberalization, 1991-2003.” Journal of Banking and Finance 29 (8-9): 2325-53.

Haber, Stephen. 2006. “Authoritarian Government.” In The Oxford Handbook of Political Economy, ed. Barry R. Weingast and Donald Wittman. Oxford: Oxford University Press.

Haber, Stephen. 2007. "Political Institutions and Financial Development: Evidence from the Political Economy of Banking Regulation in the United States and Mexico.” In The Politics of Financial Development, ed. Stephen Haber, Douglass C. North, and Barry R. Weingast. Palo Alto: Stanford University Press.

Haber, Stephen. Forthcoming. "Why Banks Don't Lend: The Mexican Financial System.” In No Growth without Equity? Inequality, Interests, and Competition in Mexico, ed., Santiago Levy and Michael Walton. Washington and London: World Bank/Palgrave.

Haber, Stephen, Herbert S. Klein, Noel Maurer, and Kevin Middlebrook. Forthcoming. Mexico Since 1980. Cambridge: Cambridge University Press.

Haber, Stephen, Douglass C. North, and Barry R. Weingast. 2007. Political Institutions and Financial Development. Stanford: Stanford University Press.

Haber, Stephen, Armando Razo, and Noel Maurer. 2003. The Politics of Property Rights: Political Instability, Credible Commitments, and Economic Growth in Mexico, 1876-1929. Cambridge: Cambridge University Press

Halac, Marina, and Sergio L. Schmukler. 2004. "Distributional Effects of Crises: The Financial Channel.” Economica, 5(1): 1-67.

Hammond, Bray. 1947. "Jackson, Biddle, and the Bank of the United States,” The Journal of Economic History 7 (1): 1-23.

Hanley, Anne G. 2005. Native Capital: Financial Institutions and Economic Development in Sao Paulo, Brazil, 1850-1905. Palo Alto: Stanford University Press.

Harstad, Bard and Jakob Svensson. 2006. “Bribes, Lobbying and Development.” CEPR Discussion Paper No. 5759. 
Hart, Oliver. Firms, Contracts and Financial Structure. Oxford: Oxford University Press.

Hause, John C., and G. du Rietz. 1984. "Entry, Industry Growth, and the Microdynamics of Industry Supply.” Journal of Political Economy, 92(4): 733-757.

Henry, Peter Blair. 2000a. "Stock Market Liberalization, Economic Reform, and Emerging Market Equity Prices.” Journal of Finance, 55(2): 529-564.

Henry, Peter Blair. 2000b. “Do Stock Market Liberalizations Cause Investment Booms?” Journal of Financial Economics, 58(1-2): 301-334.

Henry, Peter B. 2003. "Capital Account Liberalization, the Cost of Capital and Economic Growth.” American Economic Review, 93(2): 91-96.

Henry, Peter B. 2006. “Capital Account Liberalization: Theory, Evidence, and Speculation.” NBER Working Paper No. 12698.

Högfeldt, Peter. 2004. The History and Politics of Corporate Ownership in Sweden. NBER Working Paper No. 10641.

Horwitz, Morton J. 1976. The Transformation of American Law, 1780-1860. Cambridge: Harvard University Press.

Johnson, Simon, Peter Boone, Alasdair Breach, and Eric Friedman. 2000. "Corporate governance in the Asian financial crisis." Journal of Financial Economics, 58(1-2): 141-186.

Johnson, Simon, John McMillan, and Christopher Woodruff. 2000. "Entrepreneurs and the Ordering of Institutional Reform.” The Economics of Transition, 8(1): 1-36.

Johnson, Simon, John McMillan, and Christopher Woodruff. 2002. "Property Rights and Finance.” American Economic Review, 92: 1335-1356.

Johnson, Simon and Todd Mitton. 2003. "Cronyism and Capital Controls: Evidence from Malaysia." Journal of Financial Economics, 67(2): 351-382.

Johnson, Simon, Peter Boone, Alasdair Breach, and Eric Friedman. 2000. "Corporate Governance in the Asian Financial Crisis.” Journal of Financial Economics 58(1-2): 141-186.

Keefer, Philip. 2001. “Elections, Special Interests and the Fiscal Costs of Financial Crisis.” Mimeo World Bank.

Keyssar, Alexander. 2000. The Right to Vote: The Contested History of Democracy in the United States. New York: Basic Books.

Khanna, Tarun and Krishna Palepu. 2000. "Is Group Affiliation Profitable in Emerging Markets ? An Analysis of Diversified Indian Business Group.” Journal of Finance, 55(2): 867-91.

Khanna, Tarun and Yishay Yafeh. 2007. "Business Groups in Emerging Markets: Paragons or Parasites ?” Journal of Economic Literature, 45: 331-372.

King, Robert G., and Ross Levine. 1993. "Finance and Growth: Schumpeter Might Be Right.” Quarterly Journal of Economics, 108(3): 717-37.

Khwaja, Asim Ijaz and Atif Mian. 2005. "Do Lenders Favor Politically Connected Firms: Rent Provision in an Emerging Financial Market.” Quarterly Journal of Economics, 120(4): 1371-1411. 
Klapper, Leora, Luc Laeven and Raghuram Rajan. 2006. "Entry Regulation as a Barrier to Entrepeneurship.” Journal of Financial Economics, 82(3):591-629.

Kroszner, Randall S., and Philip E. Strahan. 1999. "What Drives Deregulation? Economics and Politics of the Relaxation of Bank Branching Restrictions.” Quarterly Journal of Economics, 114(4): 1437-67.

La Porta, Rafael, Florencio López-de-Silanes, and Guillermo Zamarripa. 2003. "Related Lending.” Quarterly Journal of Economics 118 (1): 231-68.

Lamoreaux, Naomi. 1994. Insider Lending: Banks, Personal Connections, and Economic Development in Industrial New England. Cambridge: Cambridge University Press.

Lamoreaux, Naomi, and Jean-Laurent Rosenthal. 2004. "Corporate Governance and the Plight of Minority Shareholders in the United States Before the Great Depression.” NBER Working Paper No. 10900.

Lane, Carl. 1997. "For a 'Positive Profit': The Federal Investment in the First Bank of the United States, 1792-1802.” William and Mary Quarterly, 54(3): 601-12.

La Porta, Rafael, Florencio Lopez-De-Silanes, and Andrei Shleifer. 1999. “Corporate Ownership Around the World.” Journal of Finance, 54(2): 471-517.

La Porta, Rafael, Florencio Lopez-de-Silanes, Andrei Shleifer. 2002. “Government Ownership of Banks.” Journal of Finance, 57(1): 265-301.

La Porta, Rafael, Florencio Lopez-de-Silanes, and Andrei Shleifer. 2006. "What Works in Security Laws.” Journal of Finance, 61(1): 1-32.

La Porta, Rafael, Florencio Lopez-de-Silanes, Andrei Shleifer, and Robert W. Vishny. 1997. "Legal

Determinants of External Finance.” Journal of Finance, 52(3): 1131-1150.

La Porta, Rafael, Florencio Lopez-de-Silanes, Andrei Shleifer, and Robert W. Vishny. 1998. "Law and Finance.” Journal of Political Economy 106(6): 1013-1155.

La Porta, Rafael, Florencio Lopez-de-Silanes, and Guillermo Zaparripa. 2003. "Related Lending.” Quarterly Journal of Economics, 108(1): 231-268.

La Porta, Rafeal, Florencio Lopez-de-Silanes and Andrei Shleifer (2007), 'The Economic Consequences of Legal Origins', NBER working paper 13608; forthcoming, Journal of Economic Literature.

Lee, Keun., M. Peng and K. Lee (2001), “Institutions and Changing Performance of Corporate Groups: The Case of the Chaebol in Korea.” Mimeo Korea Institute of Finance

Levine, Ross. 2005. “Law, Endowments, and Property Rights.” Journal of Economic Perspectives, 19(3): 61-88.

Levine, Ross. 2004. "Finance and Growth: Theory and Evidence.” In Handbook of Economic Growth. Vol. 1A, ed. Philippe Aghion and Steven Durlauf, 865-934. The Netherlands: Elsevier Science.

Licht, Amir, Jordan Siegel and Shalom Schwartz. 2006. "Egalitarism and International Investment”, Mimeo Harvard University.

Lindert, Peter H. 1994. “The Rise of Social Spending, 1880-1930.” Explorations in Economic History, 31(1): 1-37.

Londregan, John B. and Keith T. Poole. 1990. "Poverty, the Coup Trap, and the Seizure of Executive Power.” World Politics, 42(2): 151-183.

Machiavelli, Niccolo. 2005. The Prince. Oxford: Oxford University Press. 
Malmendier, Ulrike.2005. "Roman Shares.” In The Origins of Value. The Financial Innovations that Created Modern Capital Markets, ed. W. Goetzmann, and G. Rouwenhorst, 31-42, 361-365. Oxford: Oxford University Press.

Maurer, Noel. 2002. The Power and the Money: The Mexican Financial System, 1876-1932. Palo Alto: Stanford University Press.

Maurer, Noel and Andrei Gomberg. 2005. "When the State is Untrustworthy: Public Finance and Private Banking in Porfirian Mexico.” Journal of Economic History, 64(4): 1087-1107.

Maurer, Noel, and Stephen Haber. 2007. "Related Lending and Economic Performance: Evidence from Mexico.” Journal of Economic History 63 (3).

McGuire, Martin and Mancur Olson. 1996. “The Economics of Autocracy and Majority Rule: The Invisible Hand and the Use of Force.” Journal of Economic Literature, 34(1): 72-102.

McMillan, John, and Christopher Woodruff. 2002. "The Central Role of Entrepreneurs in Transition Economies.” Journal of Economic Perspectives, 16(3): 153-170.

Mihir, Desai A., Alexander Dyck, and Luigi Zingales. “Theft and Taxes.” Journal of Financial Economics, 84(3): 591-623.

Modigliani, Franco, and Enrico Perotti. 2000. "Security Markets versus Bank Finance: Legal Enforcement and Investor Protection.” International Review of Finance, 1: 81-96.

Morck, Randall, Daniel Wolfenzon, and Bernard Yeung. 2006. "Corporate Governance, Economic Entrenchment, and Growth.” Journal of Economic Literature, 43: 657-722.

Morck, Randall, and Bernard Yeung. 2004. "Family Control and the Rent-Seeking Society."

Entrepreneurship: Theory and Practice, 28 (4): 391-409.

Moss, David and Sarah Brennan. 2004. "Regulation and Reaction: The Other Side of Free Banking in Antebellum New York.” Harvard Business School Working Paper 04-038.

Musacchio, Aldo. 2007. "Law, Politics, and Finance: Creditor Rights, Contract Enforcement, and the Rise and Decline of Bond Markets in Brazil, 1850-2002.” In The Politics of Financial Development, ed. Stephen Haber, Douglass C. North, and Barry R. Weingast. Palo Alto: Stanford University Press.

Neal, Larry. 1990. The Rise of Financial Capitalism: International Capital Markets in the Age of Reason. Cambridge: Cambridge University Press.

Ng, Kenneth. 1988. "Free Banking Laws and Barriers to Entry in Banking, 1838-1860.” The Journal of Economic History, 48(4): 877-889.

North, Douglas C. 1991. “Institutions.” Journal of Economic Perspectives, 5(1): 97-112.

North, Douglass C., William R. Summerhill, and Barry R. Weingast. 2000. "Order, Disorder, and Economic Change: Latin America versus North America." In Governing for Prosperity, ed. Bruce Bueno de Mesquita and Hilton L. Root, 17-58. New Haven: Yale University Press.

North, Douglass C., and Robert Paul Thomas. 1996. Rise of the Western World: a New Economic History. Cambridge, Eng: Cambridge University Press.

North, Douglass C., and Barry R. Weingast. 1989. “Constitutions and Commitment: The Evolution of Institutions Governing Public Choice in Seventeenth-Century England.” The Journal of Economic History, 44 (4): 803-32.

Ober, Josiah. 1998. Political Dissent in Democratic Athens. Princeton: Princeton University Press. 
Olson, Mancur. 1993. "Dictatorship, Democracy, and Development." American_Political Science Review, 87(3): 567-576.

Olson, Mancur. 2000. Power and Prosperity: Outgrowing Communist and Capitalist Dictatorships. New York: Basic Books.

Pagano, Marco and Paolo Volpin. 2001. "The Political Economy of Finance.” Oxford Review of Economic Policy, 17(4): 502-519.

Pagano, Marco and Paolo Volpin. 2005. “The Political Economy of Corporate Governance.” American Economic Review, 95(4): 1005-1030.

Pagano, Marco and Paolo Volpin. 2006. "Shareholder Protection, Stock Market Development, and Politics.” Journal of the European Economic Association, 4(2-3): 315-341.

Perotti, Enrico. 2002. "Lessons from the Russian Meltdown: The Economics of Soft Legal Constraints." International Finance, 5(3): 359-399.

Perotti, Enrico and Armin Schwienbacher. 2007. “The Political Origin of Pension Funding.” CEPR Discussion Paper No. 6100.

Perotti, Enrico and Ernst-Ludwig von Thadden. 2006. "The Political Economy of Corporate Control and Labor Rents.” Journal of Political Economy, 114(1): 145-174.

Perotti, Enrico and Paolo Volpin. 2004. "Lobbying on Entry.” Tinbergen Institute Discussion Paper No. 04$088 / 2$.

Perotti, Enrico and Paolo Volpin. 2007. “Investor Protection and Entry.” Tinbergen Institute Discussion Paper No. 07-006/2.

Persson, Thorsten, Gerard Roland, and Guido Tabellini. 1997. "Separation of Powers and Political Accountability.” Quarterly Journal of Economics, 112(4): 1163-1202.

Persson, Torsten and Guido Tabellini. 2003. The Economic Effects of Constitutions. Cambridge:MIT Press.

Rajan, Raghuram and Rodney Ramcharan (2007), 'Landed Interests and Financial Underdevelopment in the United States', University of Chicago working paper

Rajan, Raghuram, and Luigi Zingales. 1998. "Financial Dependence and Growth.” American Economic Review, 88(3): 559-86.

Rajan and Zingales (2003), 'The Great Reversals: the Politics of Financial Development in the Twentieth Century', Journal of Financial Economics, volume 69:1, pp.559-586

Rajan, Raghuram, and Luigi Zingales. 2003a. “Saving Capitalism from Capitalists”, Random Books.

Rogoff, Kenneth, M. Ayhan Kose, Eswar Prasad, and Shang-Jin Wei. 2006. "Effects of Financial Globalization on Developing Countries: Some Empirical Evidence.” IMF Occasional Papers No. 220.

Razo, Armando. Forthcoming. Social Foundations of Limited Dictatorship: Networks and Private Protection during Mexico’s Early Industrialization. Palo Alto: Stanford University Press. 
Robinson, James A. 2001. “When is a State Predatory?” CESifo Working Paper No. 178.

Rockoff, Hugh. 1974. “The Free Banking Era: A Reexamination.” Journal of Money, Credit, and Banking, 6(2): 141-67.

Rockoff, Hugh. 1985. "New Evidence on Free Banking in the United States.” The American Economic Review, 75(4): 886-889.

Rockoff, Hugh. 2000. “Banking and Finance, 1789-1914.” In The Cambridge Economic History of the United States Vol. II, ed. Stanley Engerman and Robert Gallman, 643-684.Cambridge, Eng.: Cambridge University Press.

Roe, Mark. 2003. Political Determinants of Corporate Governance: Political Context, Corporate Impact. New York: Oxford University Press.

Rousseau, Peter. 2003. “Historical Perspectives on Financial Development and Economic Growth.” Review of the Federal Reserve Bank of St. Louis, 84 (4): 81-105.

Rousseau, Peter, and Richard Sylla. 2003. "Financial Systems, Economic Growth, and Globalization.” In Globalization in Historical Perspective, ed. Michael Bordo, Alan Taylor, and Jeffrey Williamson, 373-413. Chicago: The University of Chicago Press.

Rousseau, Peter, and Richard Sylla. 2004. "Emerging Financial Markets and Early U.S. Growth.” Explorations in Economic History, 42 (1): 1-26.

Rousseau, Peter and Paul Wachtel. 1998. "Financial Intermediation and Economic Performance: Historical Evidence from Five Industrialized Countries.” Journal of Money, Credit, and Banking, 30 (4): 657-78.

Sapienza, Paola. 2004. “The Effects of Government Ownership on Bank Lending.” Journal of Financial Economics, 72(2): 357-384.

Schleifer, Anrei, and R.W. Vishny. 1993. “Corruption.” Quarterly Journal of Economics, 108(3): 599-617.

Sonin, Constantine. 2003. "Why the Rich May Favor Poor Protection of Property Rights.” Journal of

Development Economics, 31(4): 715-31.

Soskice, David W., Peter A. Hall. 2001. Varieties of capitalism: the institutional foundations of comparative advantage. Oxford: Oxford University Press.

Stasavage, David. 2003. Public Debt and the Birth of the Democratic State: France and Great Britain, 1688-1789. Cambridge: Cambridge University Press.

Stigler, George. 1971. “The Theory of Economic Regulation.” Bell Journal of Economics and Management Science, 2(1): $3-21$.

Stulz, Rene. 2005. “The limits of financial globalization.” Journal of Finance, 60(4): 1595-1638.

Stulz, Rene, and Rohan Williamson. 2003. “Culture, Openness, and Finance.” Journal of Financial Economics, 70(3): 313-349.

Summerhill, William R. Forthcoming. Inglorious Revolution: Political Institutions, Sovereign Debt, and Financial Underdevelopment in Imperial Brazil. Cambridge: Cambridge University Press.

Svensson, Jakob 2005. “Eight questions about Corruption.” Journal of Economic Perspectives, 19(5): 1942 
Sylla, Richard. 1969. "Federal Policy, Banking Market Structure, and Capital Mobilization in the United States, 1863-1913.” Journal of Economic History, 29 (4): 657-86.

Sylla, Richard. 1975. The American Capital Market, 1846-1914 : A Study of the Effects of Public Policy on Economic Development. New York: Arno Press.

Sylla, Richard. 2000. “Experimental Federalism: The Economics of American Government, 1789-1914.” In The Cambridge Economic History of the United States Vol. II, ed. Stanley Engerman and Robert Gallman, 483-542. Cambridge: Cambridge University Press).

*Sylla, Richard. 2005. “The Political Economy of Early US Financial Development.” .

Sylla, Richard. 2006. "The Political Economy of Financial Development: Canada and the United States in the Mirror of the Other, 1790-1840.” Enterprise \& Society 7(4): 653-665.

Sylla, Richard, John B. Legler, and John Wallis. 1987. "Banks and State Public Finance in the New Republic: The United States, 1790-1860.” The Journal of Economic History, 47(1-2): 391-403.

Tabellini, Guido (2007) Institutions and Culture, EEA Presidential Lecture, mimeo, IGIER, Milano

Temin, Peter. 1968. “The Economic Consequences of the Bank War.” The Journal of Political Economy, 76(2): 257-274.

Triner, Gail. 2001. Banking and Economic Development: Brazil, 1889-1930. London: Palgrave MacMillan.

Tullock, Gordon. 1987. Autocracy. Boston: Kluwer Academic Publishers.

Wallis, John, Richard Sylla, and John B. Legler. 1994. "The Interaction of Taxation and Regulation in Nineteenth Century U.S. Banking.” In The Regulated Economy: A Historical Approach to Political Economy, ed. Claudia Goldin and Gary D. Libecap, 122-144. Chicago: The University of Chicago Press.

Wallis John and Weingast, Barry R., 2005. "Equilibrium Impotence: Why the States and Not the American National Government Financed Infrastructure Investment in the Antebellum Era.” NBER Working Paper 11397.

Wang, Ta-Chen. 2006. “Courts, Banks, and Credit Market in Early American Development.” Ph.D. diss. Stanford University.

Wintrobe, Ronald. 2000. The Political Economy of Dictatorship. Cambridge: Cambridge University Press.

Wright, Robert E. 1999. "Bank Ownership and Lending Practices in New York and Pennsylvania, 17811831.” The Business History Review, 73(1): 40-60.

Wurgler, Jeffrey. 2000. “Financial Markets and the Allocation of Capital.” Journal of Financial Economics, 58(1-2): 187-214. 